3 Mark W. Jessell ${ }^{1,2}$, Graham C. Begg ${ }^{2,3}$, Meghan S. Miller $^{4}$

4 'Laboratoire GET, Université Toulouse 3 Paul Sabatier, IRD, CNRS UMR 5563, Observatoire Midi5 Pyrénées, 31400 Toulouse, France.

$6{ }^{2}$ Centre for Exploration Targeting, The University of Western Australia, 35 Stirling Highway, Crawley,

7 WA, 6009, Australia

$8{ }^{3}$ Minerals Targeting International, Suite 26, 17 Prowse Street, West Perth WA 6005, Australia

$9{ }^{4}$ Department of Earth Sciences, Zumberge Hall of Science (ZHS), 3651 Trousdale Pkwy, Los 10 Angeles, CA 90089-0740

11

12

13 Corresponding Author:

14 Mark Jessell

$15 \quad$ Tel +61 864885803

$16 \quad$ Fax +61864881178

17 E-mail Mark.Jessell@uwa.edu.au

18

19 
This paper examines existing and newly compiled geophysical representations of the West African Craton (WAC) in terms of its large-scale tectonic architecture. In order to build an interpretation with a significant depth extent we draw upon a range of geophysical data, principally seismic tomographic inversions, receiver functions, gravity and magnetics. We present these results as a series of layers providing a series of depth slices though the cratonic lithosphere. The different geophysical methods suggest partitioning of the WAC into two tectonic elements at the largest scale which is observed in both seismic tomographic images, lithosphere-asthenosphere boundary (LAB) models and long wavelength gravity signals. The different models of the Moho, or crust-mantle boundary, based on these gravity or seismic datasets show little or no correlation, either for short or long-wavelength features, and show little correlation with new receiver function inferred crustal thickness estimates. Manual interpretation of low-wavelength gravity and magnetic data suggest a possible continuation of the WAC across the western margin of the modern boundary, and also highlight distinct domains interpreted to be of Birimian age.

1. Introduction

The West African Craton (WAC) extends across western Africa, and consists of two Archean nuclei in the north-western and south-western parts of the craton juxtaposed against an array of Paleoproterozoic domains made up of greenstone belts, sedimentary basins and regions of extensive granitoid-TTG plutons, which are overlain by Neo-Proterozoic and younger sedimentary basins (Fig. 1).

The borders of the WAC are largely defined by a combination of surface geology and gravity signature (Burke and Whiteman, 1973; Lesquer et al, 1984; Roussel \& Lesquer, 1991; Ennih and Liegeois, 2008). Debates around the first-order tectonic architecture of the craton have been based on petrographic and structural variations as measured at the surface, with depth interpretations 
architectures are effectively two-dimensional and limit a full understanding of crustal scale structure and large regions of metal potential.

47 The deep structure of the crust and Subcontinental Lithospheric Mantle (SCLM) can play a crucial role in controlling the location of major mineral systems, as has been highlighted by Cassidy \& Champion (2004), Begg et al. (2010), Griffin et al. (2013). This study combines existing analyses with previously unpublished inversions, new P-wave receiver function estimates and manual interpretations of the gravity and magnetic anomaly maps in order to examine the geophysical database for the WAC in terms of its large-scale tectonic architecture. In order to build an interpretation with significant depth extent we draw upon a range of geophysical data, principally seismic tomographic inversions, gravity and magnetics. We present these results as a series of horizontal slices through the crust and upper mantle leading to an integrated 3D model though the lithosphere.

No single dataset is able to unravel the structural architecture alone, and the absolute values of predicted properties probably have only general significance since the variations in petrophysical properties can have a range of causes. Instead, we have taken a multi-data and multi-study approach that attempts to find correlations between different studies attempting to describe the same property, and to look for correlations in the spatial variations between properties. In this we support and generalise to all types of geophysical data the assertion of Foulger et al. (2013): "If a feature imaged by tomography is reliable, it should be resolvable in multiple independent studies. Geological significance should only be attributed to features The drawback to taking this approach with multiple datasets is that they do not generally measure the same petrophysical properties, and their observation depth range varies as well, however correlations in features in such datasets make powerful arguments for the presence 
of fundamental structures, whereas conflicting results from different measurements are not "wrong" but are often harder to interpret. Each individual model that results from inversion have their own absolute error estimates, and limitations due to the spatial coverage and depth smearing, however the we have worked on the principal that significant correlations between two models or datasets attempting to predict the same features are a more robust demonstration of significance than error estimates internal to any one dataset.

The aim of this paper is simply to document the range of geophysical observations that pertain to the WAC, so that we can define those features that can reliably be used as the basis for studies attempting to define the tectonic evolution of the region. This tectonic evolution itself is constrained by the geophysics, but equally by the surface geology, geochemistry and metallogenesis and is thus beyond the scope of this current work.

\section{The Geology of the West African Craton}

\subsection{The Baoulé-Mossi Paleoproterozoic domain}

The oldest rocks in West Africa are Archean in age (with a major peak at $2850 \mathrm{Ma}$ ) and are found in western Côte d'Ivoire, Liberia, Sierra Leone and southern Guinea in the south and Western Sahara and Mauritania in the north. They consist of felsic and mafic gneisses and migmatites associated with narrow greenstone belts of lower grade rocks. The belts are composed of metamorphosed tholeiitic basalts and metasediments including turbidites, conglomerates and extensive banded iron formation.

The Baoulé-Mossi domain (Fig. 1) is found to the north and east of the Kénéma-Man Archean domain (Bessoles, 1977). The Paleoproterozoic domain is characterized by the Archean-like greenstone-granitoid assemblages that principally consist of volcanic, volcano-sedimentary, and sedimentary sequences separated by extensive tonalite-trondhjemite-granodiorite and granite 
provinces, or alternatively by slightly younger sedimentary basins whose basement is not exposed. The volcanic and volcano-sedimentary rocks belong to the Birimian Supergroup, which is thought to have formed in the context of volcanic arcs and oceanic plateaus (Abouchami et al., 1990; Béziat et al., 2000; Boher et al., 1992; Leube et al., 1990; Pouclet et al., 1996). Radiometric dating of the volcanic units (Davis et al., 1994; Lüdtke et al., 1998; Lüdtke et al., 1999) places the main peak of the Birimian volcanism at around $2190-2160 \mathrm{Ma}$, while detrital zircons from the sedimentary basins yield ages as young as $2130 \mathrm{Ma}$ (Lüdtke et al., 1999) or 2107 Ma (Doumbia et al., 1998). The Birimian volcanic and volcano-sedimentary units are unconformably overlain at several places across the craton by late basins, which are collectively known as the Tarkwaian or Tarkwa-like sediments since their relative ages are poorly constrained (Feybesse et al., 2006; Whitelaw, 1929; Sestini, 1973; Leube et al., 1990; Oberthür et al., 1998). The whole complex of volcanic, volcano-sedimentary and sedimentary units has been intruded by several generations of granitoids, which were emplaced during discrete magmatic pulses from 2180 to 2040 Ma (Agyei Duodu et al., 2009; Castaing et al., 2003; Doumbia et al., 1998; Gasquet et al., 2003; Hirdes et al., 1996; Leube et al., 1990; Naba et al., 2004; Gueye et al., 2008; Pons et al., 1995, Baratoux et al., 2011; Perrouty et al., 2012). The general geochemistry of the granitoids evolves from Na-rich calc-alkaline to K-rich alkaline (Boher et al., 1992) while their shape depends on the tectonic regime during their emplacement, ranging from undeformed circular plutons to elongate and complex interlocking bodies (Pons et al., 1995, Jessell et al., 2012).

The limits of the West African Craton has evolved with time, as craton outlines are diachronous that is, they vary through time as some fragments of continental lithosphere are either joined to, or separated from, an existing large block of internally stable continental lithosphere (a craton). For instance, the eastern half of the Reguibat craton sutures to the WAC at ca 2070 Ma (Schofield and Gillespie, 2007; Fig. 1). The eastern boundary of WAC, defined by the Late Neoproterozoic (PanAfrican) Dahomeyan and Pharusian terranes of the Trans-Saharan orogenic belt (Black et al., 1979; 
Black and Liégeois, 1993), is identified with reasonable confidence. The other boundaries are either artefacts of later plate movements or less well understood. The northern boundary is obscured beneath the Anti-Atlas Mountains. The southern boundary is an artefact of Atlantic opening (southern WAC terranes appear to correlate with, and were likely once contiguous with, those of the Guiana Shield in South America). The western boundary lies offshore - it is not known precisely how far the craton extended to the west at 2050 Ma. The present study focuses on the interior of the craton, in contrast to its margin, which were the subject of IGCP 485 (Ennih and Liégeois, 2008), which describe the younger (post-Proterozoic) history.

2.2 Tectonic Evolution 
are undertaken (Parra-Avila, 2015). Gold mineralization in West Africa is generally related to these shear zones (e.g. Allibone et al., 2002a \& b, Allibone et al., 2004; Blenkinsop et al., 1994; Bourges et al., 1998; Feybesse et al., 2006; Milési et al., 1989; Milési et al., 1992; Tshibubudze and Hein, 2013a), although the Wassa gold deposit in SW Ghana appears to have formed very early in the structural evolution of the Ashanti Belt (Perrouty et al., 2015). The consolidated Eburnean basement was then unconformably overlain by the Mesoproterozoic to Palaeozoic sediments of the Taoudeni, Lullemeden and Volta basins (Teal \& Kah, 2005; Rooney et al., 2010). Dyke swarms cross the entire Proterozoic domain in several directions and were emplaced during at least six magmatic events with ages ranging from $1791 \mathrm{Ma}$ to $200 \mathrm{Ma}$ (Baratoux et al., 2014, Jessell et al., 2015)

3. The Internal Structure of the West African Sub-continental Lithosphere (SCLM) and the Lithosphere-Asthenosphere Boundary (LAB)

The lithosphere-asthenosphere boundary denotes the theoretical limit between the Earth's "rigid" outer shell that forms the plates which translate in continental drift and sea-floor spreading and the "weak", convecting layer, the asthenosphere. A more formal definition (e.g. Sleep 2005) describes the rigid lithosphere as the portion of the thermal boundary layer in which heat transport is purely conductive, and that the base of the thermal boundary layer represents a rheological boundary between the lithosphere and the convecting mantle below. Xenoliths from deep within the continents suggested that the continental lithosphere (first termed the tectosphere) is composed of cold, high-viscosity mantle layers which are balanced by their (depleted) chemical compositions (e.g. Jordan 1975,1978$)$. However, the definitions and interpretations of the LAB can vary depending on the geophysical technique used, as definitions include specific isotherms, observed receiver function signals and magnetotelluric transitions (e.g. Eaton et al., 2009; Fischer et al., 2010), and in any case is probably not a sharp boundary. 
Despite the ambiguity in LAB depth estimates, a detailed, 3D knowledge of lithospheric properties can aid in understanding how deformation is distributed within continents. As we go deeper into the Earth, each geophysical method tends to highlight distinct features, which is not all that surprising given the range of physical properties that underpin these methods, and the different depth extent that they image. As the most relevant properties (petrology, mechanics and structure) cannot be measured directly, they have to be inferred from proxies. These proxies can be based on observations of heat flow, isotropic and anisotropic seismic velocity, electrical conductivity, potential fields and topography. Another potential problem is that seismic tomographic studies and elastic thickness studies typically rely on a priori models of crustal structure, such as the 3SMAC model (Nataf and Ricard, 1996), Crust 5.1 (Mooney et al., 1998) Crust 2.0 (Bassin et al., 2000) or Crust 1.0 (Laske et al., 2013) to account for "shallow" structure, so some correlations between these studies could simply reflect their common usage of these models. In this study we will see that for the WAC different approaches, using different a priori models of the crust, have led to lithospheric models with first order structure, suggesting that at this is not an issue in this region.

3.1. The internal structure of the SCLM

The internal structure of the SCLM and the topography of the lithosphere-asthenosphere boundary (LAB) has been the focus of a number of studies at both the global and African scales. The principal geophysical information comes from inversions that fall into one of four types of observation: Swave tomography (Vs) from global datasets, regional P-wave tomography (Vp); shear-wave splitting (anisotropy of Vs); and receiver functions from teleseismic $\mathrm{S}$ and $\mathrm{P}$ conversions at a velocity discontinuity.

The first two provide information about the variations of different wave velocities and the third provides information on inferred seismic anisotropy from alignment of anisotropic fabrics or 
minerals. The fourth provides information about the boundary layer depths within the lithosphere and/or at its base from the conversion of seismic waves at these interfaces.

The $\mathrm{P}$ and $\mathrm{S}$ wave velocities can be interpreted in terms of the current thermal structure of the Earth, and/or in terms of its composition:

a. Thermal Structure (Afonso et al., 2005): there is a strong effect of temperature variation on physical properties of the upper mantle rocks, including the wave velocity (with hotter temperatures resulting in slower Vs and $\mathrm{Vp})$.

b. Chemical Composition and Mineralogy (Duffy \& Anderson, 1989; Li et al., 2004): The four major upper mantle minerals are olivine, orthopyroxene, clinopyroxene, and garnet. Compared to olivine (for XFe $=0.1$ ), calcium-rich clinopyroxene has ca. $0.8 \%$ lower S-wave velocity. For a hypothetical olivine-rich $(\mathrm{Xol}=57 \%)$ end-member of the upper mantle composition, an increase in diopside content from $12 \%$ to $18 \%$ leads to a ca. $0.4 \%$ decrease of mantle S-velocity. Apart from variations in iron, variations in garnet (more garnet $=$ higher Vs) and orthopyroxene (more orthopyroxene relative to $\mathrm{cpx}=$ higher Vs) content in the upper mantle also effects seismic velocity.

c. Fluids (Karato, 1995): At depths greater than $100 \mathrm{~km}$ (i.e. beyond the dehydration depth of most hydrous minerals) the continental upper mantle is essentially dry: the amount of water does not exceed 0.03 wt \% of olivine. However, at the sites of palaeo-subduction zones the amount of water in the mantle can increase by 3-10 times due to its downward transport and storage by dense hydrous magnesium silicates, with a resulting reduction in Vs. d. Melts (Hammond \& Humphreys, 2000): Although the presence of partial melts can be a direct consequence of high mantle temperatures, decompression or increased water content, it also implies a phase change and can be considered to be a cause of non-thermal (i.e. phase-change related) velocity anomalies (more melt $=$ lower velocities). 
The availability of large catalogues of seismic data over the last two decades has inspired an increasing number of research groups to undertake seismic tomography studies predicting global and local variations in P-waves (Vp) and S-waves (Vs). We compare five studies which have presented seismic tomographic inversions of Vs which include Africa (Fig. 3; Sebai et al, 2006; Begg et al., 2009 (reprocessing of Grand, 2011 data for this study); Simmons et al., 2010; Fishwick, 2010, Shaeffer \& Lebedev, 2013). These studies, despite being based upon inversion of surface waves (Sebai et al., 2006; Fishwick, 2010), body waves (Grand 2011 data, this study; Simmons et al., 2010) or both surface and body waves (Schaeffer \& Lebedev, 2013), all produce models that are dominated by positive Vs anomalies over the West African Craton (WAC), the Congo Craton and over southern Africa to depths of at least $400 \mathrm{~km}$.

At the scale of the WAC, a global Vs model supplied by Steve Grand of the University of Texas (an 2011 update of the model published in Grand, 2002, with significantly better ray path coverage, see Supplementary Figure 2.), and reprocessed following the interpolation methodology described in Begg et al. (2009), shows a distinct partitioning of Vs values within the WAC in the $175-400 \mathrm{~km}$ depth range (Fig. 2), and although vertical smearing in this dataset can exceed $100 \mathrm{~km}$, the double Vs anomaly extends beyond this depth range. , If we look at the same region, two of the other models (Fig. 3; Fishwick, 2010; Schaeffer \& Lebedev, 2013, see their section B-B' for a vertical Vs section traversing this region) resolve a NE trending lower Vs zone (within the overall high velocity difference of the WAC) trending from eastern Sierra Leone to the junction of Niger, Mali and Algeria, which we shall examine in detail in the next section.

As discussed above, thehe overall relative positive Vs perturbations in the cratons can be interpreted in a number of ways, and the linear lower velocity trend can equivalently therefore be interpreted either as a thermal or non-thermal (compositional, water content, presence of partial melts) anomaly. Artemieva (2009) has attempted to deconvolve these factors by estimating and then 
241 subtracting the thermal signature in the velocity anomalies, which results in a strong NE-SW trending positive compositional anomaly that runs parallel to the above-mentioned lower Vs zone trend.

Deen et al. (2006) instead used an iterative process to assess the effects of varying both composition and temperature utilising the ranges established for lithospheric mantle composition and geotherms (from xenolith/xenocryst studies), respectively. They showed that the highest velocities in the 100$175 \mathrm{~km}$ depth layer in the Grand (2002) Vs model could only be approximated by the combination of cool geotherms and a relatively depleted (Fe-poor, Mg-rich) composition typical of Archean SCLM (e.g. Griffin et al., 2008). Using a thermodynamic approach, Afonso and Schutt (2012) confirmed the correlation between higher Vs anomalies in the shallow SCLM (e.g. 100-175 km) and depleted compositions. Increasing overprinting of the SCLM by asthenospheric melts results in net addition of Fe to the lithosphere (refertilisation) and a lower velocity response. This interpretation could explain some of the lateral transitions in velocity patterns without the need to invoke thermal anomalism. There is no obvious surface manifestation (e.g. volcanism, Neotectonic activity) of a modern thermal anomaly along or parallel to the lower Vs zone (Fig. 3).

Studies by Becker \& Boschi (2002), Simmons et al. (2010) and Hansen et al. (2012), not reproduced in this paper, also show significant low Vp zones beneath the WAC, however there is a larger range in observed patterns. The Simmons et al. (2010) GyPSuM model is the only one that resolves a low velocity zone that roughly coincides with the Archean part of the craton centred on Liberia. It also resolves a slightly higher velocity zone within the low velocity zone that correlates with the linear features found in the Vs tomography, but is less pronounced, and the signal is very weak and may be within the noise limit of the model. 
The exact topography of the lithosphere-asthenosphere boundary (LAB) varies according to the measurement technique (e.g. Eaton et al., 2009; Fischer et al., 2010). Tomographic images, especially at the scale of Africa or the West African Craton, inherently produce smoothed or broad (100-200 km ranging) depth estimates due to the nature of the inversions and sparse seismic station spacing. We first focus on four recent surface wave tomography studies, based on surface-wave seismic data but using different inversion schemes that have presented seismic tomographic inversions of Vs for Africa, and which have enabled the authors to make predictions of the topography of the LAB. These are chosen over body-wave tomography as the vertical incident body waves that are typically used produce large uncertainties in LAB depth.

Priestley and Tilmann (2009) determined the LAB from the surface-wave model of Africa and the relationship between shear wave speed and temperature, and then defined the LAB based on the $1315^{\circ} \mathrm{C}$ geotherm. Pasyanos (2010) carried out a regional inversion of surface wave data using a restricted model where the asthenosphere properties that underlies the lithosphere were characterised as a pre-defined step reduction in Vs and then inverted for the depth of this interface. Fishwick and Bastow (2011) follow the method of Priestley and Tilmann (2009) and finally, Pasyanos et al. (2014) calculated a global solution based on an empirical relationship between long-period group velocity and lithospheric thickness.

The inferred topography of the LAB as interpreted by Priestley and Tilmann (2009) resolves an elongate keel oriented NNE-SSW for the western domain of the WAC (Fig. 4a), whereas the Fishwick \& Bastow (2011) and Pasyanos (2010) models both show a NE-SW feature traversing the overall approximately $220 \mathrm{~km}$ depth LAB which is defined by a 10-15 km shallower LAB depth (Fig. 4b \& 4c). Finally the Litho1.0 model of Paysanos et al. (2014) also shows a NE-SW linear shallower lithosphere starting from Liberia, but differs from the other models by showing a shallow zone under Senegal and western Mauritania (Fig. 4d). If we compare these four models for a NW-SE profile (A-A', similar in location to the NW part of profile B-B' of Schaeffer \& Lebedev, 2013) cutting across the craton, 
using interpolated depths from nearest values (Fig. 5a) we can see that they display a range of depths from $175 \mathrm{~km}$ to $250 \mathrm{~km}$ over the central part of the craton, with all but the Priestley and Tilmann (2009) models showing a 10-20 km shallower LAB between two deeper regions.

It is important to note that a limitation of surface wave tomography is that surface waves cannot detect a sharp or instantaneous velocity change in the mantle which would be resolved as a broad, gradient in velocity over 100s-1000s of kilometres. Receiver functions, in particular S receiver functions (SRFs), are much better at resolving vertical changes in velocities at LAB depths beneath seismic stations than tomographic methods. Receiver functions, both P and S, are based on teleseismic converted wave analysis. When body waves hit a sub-horizontal velocity discontinuity they are partitioned into transmitted and reflected waves of various polarizations. For example, an S-wave incident upon a velocity discontinuity partitions into upward and downward propagating SV and $\mathrm{P}$ waves. Similarly, a P-wave when it encounters a sub-horizontal boundary layer also partitions into upward propagating P and SV waves. The depth of this discontinuity can then be estimated from the delay times between the converted and incident waves (Langston 1977; Vinnik 1977) for ether the $\mathrm{S}$ receiver functions (SRFs) or the $\mathrm{P}$ receiver functions (PRFs). PRFs, in particular, are commonly and successfully used for imaging the depth to the crust-mantle boundary (e.g. Zhu and Kanamori, 2000; Rondenay, 2009). One other important consideration with respect to imaging the LAB is that, unlike PRFs,SRFs do not contain "multiples" from shallower (crustal) structure in the 80$250 \mathrm{~km}$ depth range as the converted Sp phases arrive prior to the main S phase. principally cover the periphery of the craton in Morocco (Cooper and Miller, 2014; Miller and Becker, 2014; Spieker et al., 2014) and the edges of the craton in Côte d'Ivoire, Senegal, Algeria, Mali, Niger, Ghana and Nigeria (Fig 5a) (Cooper and Miller, 2014; Di Leo et al., 2015). Unfortuantely, the number of seismic stations in the southern WAC is extremely limited and the data quality is highly variable (Figure 5a). Despite the data challenges we have estimated new depths for the crustal and 
lithospheric thicknesses using both $\mathrm{S}$ and $\mathrm{P}$ receiver functions (discussed below). Although the analysis of the receiver functions produce a range of sparsely located interpretations of the Moho and LAB topography across the WAC, they represent a useful independently-derived dataset for comparison. New analyses of $\mathrm{P}$ receiver functions help constrain the depth to the Moho at 15 stations (Table 1, Figure 5a).

If we compare the estimated depth to $L A B$ from these receiver function data and those derived from seismic tomographic studies (Fig. 5c), only the Pasyanos (2010) and Pasyanos et al. (2014) show positive correlations, and only Pasyanos (2010) is at all significant (linear regression $R^{2}=0.78$ ). The receiver function data suggests a much larger range in LAB depths than the regional models, which may reflect the inherent lateral smoothing present in the regional models or the limited number of clean teleseismic events recorded at the sparsely located seismometers (e.g. Supplementary Figure 1).

Pérez-Gussinyé et al. (2009) attempted to calculate the thickness of the elastic lithosphere using a coherence function that relates the topography and Bouguer anomaly, commonly known as the Bouguer coherence. The Bouguer coherence gives information on the wavelength band over which topography and Bouguer anomaly are correlated, which in turn can be interpreted in terms of the elastic properties of the lithosphere. Unfortunately when the thickness is greater than $130 \mathrm{~km}$, the values are not resolvable, so for the WAC this does not add much to our interpretation, but at the scale of the continent resolves a similar distribution of deeper LAB over the cratons.

Gravity anomalies show a strong spatial correlation with the surface extent of cratons in Africa, with strong negative anomalies over the cratons often fringed by positive anomalies, and strong negative anomalies over many of the Mesoproterozoic-Palaeozoic basins. This is consistent with thicker, depleted (relatively Fe-poor, Mg-rich) SCLM beneath cratons (e.g. Poudjom Djomani et al., 2003). the 1980s across West Africa. His studies showed a marked reduction in crustal and lithospheric 
resistivity down to $100 \mathrm{~km}$ associated with the eastern and western margins of the WAC in Niger and Senegal (Ritz, 1983; 1984). Based on a modelled transition to lower resistivity levels, deeper imaging surveys in eastern Senegal and southern Mauritania were interpreted as showing a LAB varying between $175 \mathrm{~km}$ to the east of the craton margin to approximately $250 \mathrm{~km}$ within the craton (Ritz \& Robineau, 1988; Ritz et al, 1989).

A recent magnetotelluric traverse in Morocco supports a thick-skinned tectonic model for the High Atlas, however it did not acquire data long enough to image the LAB (Ledo et al., 2011). The WAXI Magnetotelluric survey results for SW Burkina Faso and NW Ghana (Le Pape et al., 2014) suggests a depth to the electrical LAB of approximately $250 \mathrm{~km}$ in that region that is coherent with the range of published results based on seismic studies.

\subsection{The Anisotropic Structure of the SCLM}

Seismic anisotropy studies (based on the variations in arrival time of seismic waves as a function of wave orientation) provide information which can be interpreted in terms of small scale structures including crystallographic preferred orientation andoriented micro-cracks. There are two techniques principally used to determine seismic anisotropy information: surface wave studies and teleseismic studies. Surface wave studies have good $(20-50 \mathrm{~km}$, Fishwick, 2010) vertical resolution, but relatively poor horizontal resolution (e.g. 250-300 km, Rawlison and Fishwick, 2011). Conversely teleseismic SKS studies have good horizontal resolution $(+/-25 \mathrm{~km})$ depending on the period of the wave analysed, but very limited vertical resolution, which results from the nature of SKS splitting, where the anisotropy is vertically integrated along the ray path from the core-mantle boundary to the surface.In practice the majority of the anisotropy is assumed to accumulate in the upper mantle. Ideally both should then be used, however for West Africa, the teleseismic record that is based on SKS wave paths is overall very poor (Wüstefeld et al., 2009), apart from recent studies completed in Morocco (Salah, 2012; Miller et al., 2013; Diaz \& Gallart, 2014) and Niger (Di Leo et al., 2015). 
Sebai et al. (2006) produced what is currently the highest resolution surface wave based seismic anisotropy model for West Africa, which provides a $4^{\circ}$ grid. Their results show the horizontal (azimuthal) component of the fast direction of Vs at three depths computed by surface wave tomography (Fig. 6). At a nominal $80 \mathrm{~km}$ the fast directions over the WAC are generally oriented N-S except in the SW part of the craton, where they are oriented WNW-ESE, and the SE part of the craton where the anisotropy is quite weak but trends towards NE-SW. At $180 \mathrm{~km}$, the overall anisotropy is much weaker, and the directions are dominantly NE-SW in the southern part of the craton, and E-W across the middle and northern part of the craton. In contrast, off-craton areas are dominated by NE-SW directions in Algeria and NW-SE directions in Morocco. Finally at $280 \mathrm{~km}$, which may be near to or below the LAB, the apparent fast polarization direction is predominantly NS. This type of vertical stratification of the SCLM has also been reported from other regions (Obrebski et al., 2010; Moidaki, 2014).

The inferred fast polarization directions from SKS splitting have in the past typically been interpreted in terms of the flow direction of convection in the mantle producing a crystallographic preferred orientation (e.g. Long and Becker, 2010; Sebai et al., 2006) interpreted the deepest solutions in terms of the differential motion between the African plate and the underlying mantle convection (an interpretation supported by Salah (2012), however this interpretation cannot be used for the shallower levels which are within the SCLM. Other studies included a wider range of interpretations such as melt-filled grain boundary and fracture alignments (Kendall, 1994), or compositional variations associated with metasomatised dyke arrays (Snyder \& Lockhart, 2009) and have been used to infer frozen-in anisotropy within cratons (Fouch et al., 2000; Bastow et al., 2010; Miller et al., 2013; DiLeo et al., 2015).

These results suggest that the observed vertical variations in azimuthal variation in seismic anisotropy under West Africa could be due to variations in the controls on anisotropy, rather than in the flow patterns themselves, as suggested for the East African Rift by Obrebski et al. (2010), or 
north of the WAC in north-western Africa (Alpert et al., 2013; Miller et al., 2013; Diaz \& Gallart, 2014). Improved horizontal and vertical resolution seismic anisotropy data may help us to better understand these patterns. The current poor vertical resolution of the seismic models prevents us from determining if these are in fact three distinct layers of seismic properties, or rather a gradual evolution from one local orientation to another.

Further evidence for a vertical stratification in the upper mantle comes from the interpretation of receiver function data for West Africa by Cooper and Miller (2014), who identify "mid-lithospheric discontinuities" (MLD) at 10 of the 15 stations analysed in Mali, Morocco, Ghana, and Nigeria. These MLDs occur at a depth of between 75-160 kilometres beneath stations that are located away from the edges of the craton. They interpret as remnants of tectonic structures produced during the initial formation of the craton.

\section{WAC Crustal Thickness}

As with the structure of the $L A B$, the crust-mantle boundary (also referred to as crustal thickness or the Moho) has been imaged by different techniques, namely seismic tomography, receiver function analysis and gravity inversions. There are two standard global models with a variable spatial resolution that have been developed for crustal structure, which include Moho depth estimates, based on the integration of multiple datasets, starting chronologically with 3SMAC (3-Dimensional Seismological Model A Priori Constrained; Fig. 7a, Nataf \& Ricard, 1996), which estimates crustal thickness across the WAC to be between $33-37 \mathrm{~km}$. with the area of thinnest crust centred over Mauritania. This was followed by the Crust series of models referred to by their spatial resolution (5.0, 2.0 and 1.0; Laske et al., 2013), the most recent model at $1^{\circ}$ resolution includes a crustal thickness model (Fig. 7b), which predicts a crustal thickness ranging from $36-46 \mathrm{~km}$, but which has very low horizontal spatial resolution across the West Africa. Surface wave Vs inversion has been carried out with a resolution of $1^{\circ}$ by Pasyonas \& Nyblade (2007) (Fig. 7c) to produce a crustal thickness map of Africa that predicts thicknesses ranging from $43 \mathrm{~km}$ in northern Mali to $10 \mathrm{~km}$ in 
Western Sahara, with a pronounced ridge of thicker crust extending from Algeria through to Côte d'Ivoire. Tedla et al. (2011) performed a gravity-only Euler deconvolution study of the base of the crust at a resolution of $0.25^{\circ}$ (Fig. $7 \mathrm{~d}$ ), although the validity of the processing in this model has been questioned (Reid et al., 2012; van der Meijde \& Nyblade, 2014), and their model predicts a crustal thickness range of $33-42 \mathrm{~km}$ with long wavelength variations producing an undulating effect. Bagherbandi \& Sjöberg (2012) have recently published a crustal thickness model that combines previous seismic estimates (notably CRUST2.0) with the gravity data (Fig. 7e) that predicts a thickness of 27-35 km with a tendency for thinner crust along the eastern craton margin. Tugume et al. 2013 performed a 3D inversion of EIGEN-6C gravity data, which predicts a relatively flat and shallow Moho (Fig. 7f) and thicknesses ranging from 23-33 km with long wavelength undulations in thickness. Reguzzoni et al. (2013) have produced a simple two-layer model of the Moho derived from GOCE satellite data that does not show any major structures under the WAC, and simply mimics the medium wavelength gravity structure (Fig. $7 \mathrm{~g})$, with short-wavelength $(200 \mathrm{~km})$ variations between 28 and $36 \mathrm{~km}$.. Finally Pasyanos et al. (2014) have performed a Moho depth calculation using surface waves as part of their Litho 1.0 model (Fig. 7h), which predicts a significantly larger range in crustal thicknesses than the other models, with a thickness varying between 25 and $53 \mathrm{~km}$.

Ledo et al. (2011), and Anahnah et al. (2011) estimate a Moho depth of 30-40 km based on their magnetotelluric data, although the quality of the Anahnah et al. (2011) inversions has been called in to question (Jones et al., 2012). The only additional data available for determining the depth to Moho are the results of an MT inversion by Ritz et al. 1989 for Mauritania which estimates a depth to Moho of $40 \mathrm{~km}$. The recent WAXI MT traverse across northern Ghana and SW Burkina Faso is inconclusive with respect to Moho depth as the lower crust is not conductive and therefore a contact with the mantle is not seen (Le 
To improve on these crustal thickness estimates, we collected all broadband seismic data available in the WAC from 15 stations (Table 1 ) to compute $P$ receiver functions. We analysed 540 earthquakes that were located between 30-95 degrees away from each station and has a magnitude between 6 and 8.5 (Supplemental Figure 1). The receiver functions were computed using FUNCLAB (Eagar \& Fouch, 2012). The estimates for the Moho were computed in FUNCLAB using the $H$-k stacking methodology (Zhu \& Kanamori, 2000). The number of events used for each station is highly variable depending on the length of time the station has been deployed and the quality of the data (Table 1). However, these results do provide independent and alternative constraints on the crustal thickness.

If we compare these tomographic models for our arbitrary NW-SE profile across the craton (Fig. 5a), we can see significant variations between the different models both in mean crustal thickness and the short wavelength variations (Fig. 5d), even taking into account differences in the different models' spatial resolutions. Comparison with $\mathrm{S}$ receiver functions (Fig. 5e) and $\mathrm{P}$ receiver functions (Fig. 5f) show only two models with positive correlations, both based on surface wave tomography, but the correlation coefficient is very small even for these models (Fig. 5e). As with the LAB comparisons, the receiver function data suggests a much larger range in Moho depths than the regional models.

5. Intermediate-wavelength Gravity and Magnetic Anomalies

Seismic tomographic models of the WAC, which only have a resolution of at best $1^{\circ}(\sim 110 \mathrm{~km})$, are insufficient to help us resolve structures within the crust. In order to highlight the major crustal structures we studied the regional and satellite gravity and magnetic datasets.

Gravity and magnetic datasets have been used to resolve structures at a range of scales, from the long-wavelength patterns seen in Figure $4 \mathrm{~d}$ that can be used to infer mantle heterogeneities, to the highest resolution available as an aid to 2D and 3D geological mapping (Egal et al., 2002; Feybesse et al., 2006; Bonvalot et al., 1991, Toft et al., 1992, Tidjani et al., 1993; Mickus, 2008; Hein, 2010; 
Baratoux et al., 2011; Metelka et al., 2011; Jessell et al., 2012; Perrouty et al., 2012, Jessell et al., 2015).

The long wavelength magnetic signature of the crust have been analysed by Hermant \& Maus (2005) who used the Crust 2.0 model and estimates of susceptibility for each type of crust to make a global prediction of magnetic properties. In the WAC this provides evidence for a continuation of the Reguibat Inlier for several hundred kilometres beneath the Taoudeni Basin, which could explain the Archean ages found for the Guelb Moghrein Fe oxide-Cu-Au-Co deposit in Mauritania (Meyer et al., 2006).

A number of studies have been published which use gravity and magnetic data to define cratonmargin and internal structures (Burke \& Whiteman; 1973; Bayer \& Lesquer, A., 1978; Lesquer et al, 1984, Toft \& Haggerty 1986; Bonvalot et al., 1991; Toft et al., 1992; Tidjani et al., 1993; Hartley et al., 1996; Mickus, 2008; Begg et al., 2009). For the rest of this section we follow the approach of Lesquer et al 1984, which is to identify major structures in these datasets firstly as simple geometric elements, which we then subsequently attempt to characterise in terms of age and type.

The gravity data we use is derived from the Bureau Gravimétrique International (BGI) Bouguer correction of the National Geospatial-Intelligence Agency (NGA) global gravity grid, which has a spatial resolution of 2.5 arc minutes or approximately $4.6 \mathrm{~km}$. This gravitational model is complete to spherical harmonic degree and order 2159, and contains additional coefficients extending to degree 2190 and order 2159. The underlying ground data, which consists of over 30,000 ground measurements, with most countries have an average sampling density of around 1 measurement per $60 \mathrm{sq} \mathrm{km}$, was collected over three decades from the 1950s onwards, principally by ORSTOM (Bonvalot et al., 1998 and references therein), with infill data coming from GRACE satellite data 
spacing airborne gravity gradiometry survey over the Volta Basin in Ghana (Fugro Airborne Surveys, 2009) has not been incorporated into this dataset as yet.

The magnetic dataset relies on the EMAG2 compilation, which has a resolution of 2 arc minutes, or approximately $3.7 \mathrm{~km}$ (Maus et al., 2009). We have complemented this with higher resolution magnetic data to infill gaps in this dataset when they were available. Significant coverage of airborne magnetic data has been collected in West Africa over the last twenty years, the major surveys being funded by international agencies (notably the EU, the French Ministry of Foreign Affairs, the Canadian Aid agency CIDA, and the World Bank), and only Sierra Leone lacks significant coverage of publically available airborne magnetic data. Survey line spacing varies between 200 and 20,000 m although for the craton itself the data is mostly $1000 \mathrm{~m}$ or less, and flight heights vary between 70 and $3000 \mathrm{~m}$. The total survey area is approximately $984,000 \mathrm{sq} \mathrm{km}$ over the craton or about $85 \%$ coverage.

In order to minimise the effects of near-surface structures we tried a number of low-pass filtering techniques but finally settled on a $30 \mathrm{~km}$ upward continuation to both the gravity and magnetic datasets, to which we then applied a range of standard geophysical filters (Tilt Derivative, First Vertical Derivative, Automatic Gain Control, Analytic Signal) to enhance subtle features (Fig. 8a and b).

At the scale of the craton a broad organisation of lithospheric entities is apparent. The Archean regions of the Reguibat and Leo-Man rises stand out most obviously in the magnetic data, and are characterised by high amplitude, longer wavelength highs and lows compared to other regions. Interestingly, there is a broad ENE-trending region of overall higher gravity response, and variable high and low magnetic response, across the entire craton in southern Mali. To a first order, this feature coincides with the zone of lower velocity in the lower lithosphere seen in several tomographic models discussed earlier (Figs. 2-4, and discussion further below). 

different geophysical features visible in either or both of the gravity and magnetic data (Fig. 9a). In those areas where both datasets were available and in those where they were available for adjacent areas, the major structural features could often be correlated. Although we cannot at this time directly attribute depths to these features, we will use a short-hand of calling these mid-crustal structures, even though the actual depths may vary from one structure to the next. We also recognise that reworking of structures by subsequent orogenic episodes is both possible and likely, however we have tried to assign ages based on their estimated age of formation, rather than their most recent reactivation.

This analysis produced a map of interpreted structures characterised by multiple domains consisting of one or more sets or sub-parallel linear features (Fig. 9b), with a characteristic spacing between structures of between 30 and $75 \mathrm{~km}$ ( $30 \mathrm{~km}$ being the effective cut-off wavelength introduced by the upward continuation). In any one subregion, up to three different sets of features with distinct orientations could be mapped. The overlapping structures could represent features at different depths, or alternatively they could result from the superposition of different structures at different times, or of course both. The majority of the WAC contained identifiable sets of sub-parallel structures, which we have attempted to identify in terms of their age of formation (Fig. 8b), but not their nature, as at these wavelengths we cannot be sure that they relate to single features. We have divided the structures into 6 classes of increasing "age" plus one where we could not make even a tentative assignment as follows:

e) Eburnean 
Although this is obviously a subjective classification, and reactivation of structures by younger events may well occur, following the pioneering work of Lesquer et al. (1984), this map provides a first complete image of the distribution of major crustal elements across the WAC. In the following sections we discuss these classes in turn.

\subsection{Atlas/Tethys structures}

These consist of a series of sub-parallel WNW-ESE oriented structures to the north of the WAC in

Morocco and Algeria (Fig. 10a). In surface mapping they are parallel to and spatially correlated with major north and south dipping thrusts, but do not correlate with any of the deeper geophysical features we have already discussed.

\subsection{Atlantic Opening Structures}

Major features that are coast-parallel have been associated with the opening of the Atlantic Ocean from Morocco around to Ghana (Fig. 10b). Since this coast is parallel to the Pan African structures between Morocco and Sierra Leone, it is difficult to assign them with certainty in this region (although they may be reactivated Pan African structures in any case).

In Senegal, Guinea and Côte d'Ivoire there are a series of NW-SE oriented structures resolved in the gravity data that we tentatively ascribe to Atlantic Opening, because they cut across the structural grain of the older rocks.

In Côte d'Ivoire and Ghana NE-SW structures extend from, and are parallel to the oceanic Fracture Zone $90 \mathrm{~km}$ north of the St Paul's Fracture Zone (a transform fault). Various attempts have been made to correlate offshore transforms with various onshore faults, and the Romanche FZ certainly seems to correlate with the Pan African structures along the eastern margin of the WAC (Edwards and Witmarsh, 1997; Kutu, 2014). The eastern limit of the St Paul's FZ has been interpreted as being 
governed by onshore faults in Ghana, although the high angle that these transforms make to the Eburnean structures in this area make this difficult hypothesis to confirm.

\subsection{Pan African Structures}

Approximately N-S structures dominate the eastern and western margins of the WAC, and are characterised by strong gravity highs on the outer margin of the craton, with a paired gravity low towards the craton interior (Burke \& Whiteman, 1973; Fig. 10c). To the west of these structures in Guinea, Guinea Bissau and southwestern Senegal the Pan African structures transects the older terrains in the surface geology (most notably in the Rockelides), but does not act as a limit. The Archean structures appear to continue to the west under the younger basins in both Guinea Bissau and Morocco.

\subsection{Basin Rift Structures}

For the Taoudeni and Volta basins we resolve a series of structures that have in the past been

572 interpreted as faults bounding rifts. The rifts resolve strong gravity and magnetic signatures (Fig. 9d;

573 Lesquer et al., 1984), suggesting they may be in-filled by mafic volcanics, and up to $10 \mathrm{~km}$ of graben and half-graben sediment fill in the Gourma Trough (Reichelt, 1971; Álvaro \& Vizcaïno, 2012). The rifts have been interpreted as Panafrican Aulacogen structures (Moussine-Pouchkine \& BertrandSarfati, 1978; Villeneuve, 2005). In the Taoudeni Basin the rifts form two sets, the dominant rifts being approximately E-W to ENE-WSW and a second set of transecting, and possibly younger rifts which are oriented NE-SW. The EW rifts continue to the west as far as the Senegalese Coast and their correlation with the feature seen in the $\delta \mathrm{Vs}$ inversions (Fig. 4f) suggests that they are strong candidates for reactivation of a fundamental Precambrian architecture. Birimian greenstone belts beneath the Proterozoic basin. Isopach maps for the Taoudeni (Heine, 2007) and Volta basins (Fugro, 2009) indicate maximum thicknesses of around $6000 \mathrm{~m}$, so we can 
assume that these structures, visible in our upward continued images, probably represent basement structures. They are clearly cross-cut by a NS fault (of Panafrican age?) along the eastern margin of the basin.

\subsection{Eburnean Structures}

From the Reguibat in the north to Côte d'Ivoire in the south, we identify a set of roughly N-S trending bands of alternating gravity and magnetic highs and lows (Fig. 10e), although gravity and magnetic highs and lows do not necessarily directly correlate in terms of their absolute signs or locations. Beneath the southern flank of the Taoudeni basin in Mali and further south the orientation of these features correlates with the surface expression of different greenstone belts. These can be traced further north as semi-continuous features under part of the Taoudeni Basin in Mauritania where magnetic data are available, but given the inherent lack of exposure we cannot rule out that they may be Pan-African extension-related features, or structures related to Atlantic breakup. In eastern Burkina Faso and Ghana similar structures are present, however they are oriented NE-SW, and correlate well with known Birimian greenstone belt trends. There are also E-W to NE-SW trending features beneath the Taoudeni basin that may or may not be of Birimian age (discussed above).

Although these trends are in general sub-parallel, there are two apparent truncations between sets of these structures. In western Ghana, the general NS orientation of features abuts against a series of NE-SW features. The trace of a single mid-crustal line separating these two Eburnean domains extends from the Essakane region in far northern Burkina Faso down to the eastern edge of the WaLawra belt in NW Ghana, although there does not appear to be a single surface structure that follows its entire length. Another possible NS trending truncation may exist in westernmost BF and southern Mali, although this is less clear. to the aforementioned oceanic Fracture Zones. 


\subsection{Archean Structures}

610

611

612

613

The Archean terrains are characterised by relative gravity lows compared to the Eburnean domains, and contain variably oriented features (Fig. 10f). In northwestern Mauritania, the magnetic data shows strong magnetic linear highs trending NE-SW that appear to cut obliquely across the Mauritanides, but this is not supported in the gravity data. However, similar structures seen in southern Senegal and Guinea Bissau, though interrupted by the NNW-SSE structures of the Mauritanides, seemingly continue eastwards beneath the Taoudeni basin. We have interpreted those in the north to be Archean structures based on their similar high amplitude magnetic character, but are unsure of the age of those in the south. Either way, their possible continuation either side of the Mauritanides suggests that the modern Western Margin of the Craton may not represent the original craton margin. Based on the gravity and magnetic response, there does not appear to be a continuous Archean crust joining the Reguibat and Kénéma-Man shields, although the work of Hermant and Maus (2005) suggest that the Reguibat Inlier Archean terrain extends to south for $400 \mathrm{~km}$ beneath the Taoudeni Basin. In this study we tentatively support a continuation of Archean crust up to about $370 \mathrm{~km}$ south of the large exposed Archean domain in northwest Mauritania. The NE trends in the southern Kénéma-Man are almost certainly Paleoproterozoic, based on the work of Billa et al. (1999).

\subsection{Undifferentiated Structures}

There are a few structures that appear to be important, notably a $700 \mathrm{~km}$ long NNE-SSW trending feature in Guinea and eastern Mali that does not easily fit the above categories, nor correlate with obvious surface structures (Fig. 10g).

\section{Comparisons between datasets}

In this section we draw comparisons between different features at different depths in order to get a clearer picture of the 3D structure of the WAC. Following the observations of Hartley et al. (1996), 
free-air gravity anomalies clipped at $500 \leq \lambda \leq 4000 \mathrm{~km}$ (Fig. 11a) resolve a distinct linear gravity high which coincides with the lower Vs and local ridge in the more recent LAB models, such as the Fishwick (2011) model shown in this figure. The simplest explanation for the linear gravity feature is thus the shallowing of the LAB. Local gravity highs correlate with the location of interpreted midcrustal Archean structures (Fig. 11b).

If we compare the Free Air gravity anomalies with the Grand 2011 model $\delta$ Vs contours for the 175$250 \mathrm{~km}$ interval (Fig. 11d), we can see a good correlation between the lower $\delta$ Vs feature that separates the two roots to the WAC and an ENE-oriented gravity high, suggesting that the underlying division between the two mantle roots continues into the crust.

In the southern part of the craton the mid-crustal gravity-magnetic features attributed to be of Atlantic opening age (Fig. 9b) are coincident with, and sub-parallel to the $80 \mathrm{~km}$ seismic anisotropy vectors, which may in turn reflect upper mantle dyke arrays as suggested for the Slave Province by Snyder \& Lockhart (2009). Possible surface equivalents of features with this orientation include the dense mafic dyke swarm in Liberia and a series of faults in the Volta basin. The $80 \mathrm{~km}$ Seismic Anisotropy layer from Sebai et al. (2006) shows intriguing correlations with mafic dyke swarm orientations across the WAC (Fig. 11e). When compared with by the Grand 2011 model $180 \mathrm{~km} \delta \mathrm{Vs}$ contours (Fig. 11f), the division in orientation domains between north and south in the $180 \mathrm{~km}$ seismic anisotropy vector orientations may reflect a Precambrian fabric, supporting a possible division between the northern and southern WAC. In order to better understand the relationships between the structures seen in the different geophysical datasets, we have constructed a 3D model at the scale of the craton (Fig. 12).

\section{Summary}

A suite of recent seismic tomography studies all suggest a relative high velocity (Vs) zone in the SCLM coupled with a thickened lithosphere under the major Africa cratons, including the WAC 
657 (Grand, 2002; Fishwick, 2010; Simmons et al. 2010; Schaeffer \& Lebedev, 2013). Beneath the WAC, there is a secondary structure trending NE-SW visible in the $\delta \mathrm{Vs}$ models, also visible in the depth of the estimated $L A B$ and which correlates with a long wavelength gravity high. Seismic anisotropy studies suggest that there may also be a horizontal stratification of the SCLM. If these two observations are combined we can infer a compartmentalisation of the SCLM beneath West Africa resulting in distinct volumes suggesting different long-term evolutionary paths. The depth to the LAB from MT and seismic data varies between 180 and $240 \mathrm{~km}$ across the craton. The division of the mantle into three distinct elements possibly supports the interpretation of Lesquer et al. (1984) for a "Ghanean Nucleus", with the ENE-WSW to NE-SW zone potentially demarking a "Tauodeni subcraton" separating a Leo-Man-Ghana sub-craton in the south from the Reguibat subcraton in the north as per Begg et al. (2009).

The eight models of the Moho that we compare show very little consistency, and little to no correlation with the receiver function picks. At the present day this precludes us using any of the models as constraints on the tectonic evolution of the West African Craton. This is not to say that one of the models is not correct, simply that we don't have any basis for selection. Additional receiver function studies that provide a better coverage of the inner part of the WAC could provide the constraints currently lacking for the more regional studies. The lack of an established Moho model limits our ability to correlate crustal and mantle structures, although some correlations between mid-crustal gravity-magnetic features and seismic anisotropy may exist.

The intermediate-wavelength Archean structures interpreted from gravity and magnetics in both the Reguibat and Kénéma-Man shields exhibit a concentric pattern of structures, although some of these features may be of Paleoprotorozoic age (Billa et al., 1999). There is no evidence to support the hypothesis that the two Archean domains are connected at depth beneath the Taoudeni Basin, although reworking of this central area by younger structures may mask older features, and the Archean domains do extend beyond their surface expression. 

be a continuation of Eburnean greenstone belts beneath the Taoudeni Basin, although equally they may represent the Pan-African structures. They appear to crosscut (and therefore would be potentially younger than), the ENE-WSW to NE-SW oblique features that transect the centre of the craton. Similar oblique trends are found in the southeast part of the craton including SE Burkina Faso and Ghana, and coincide with known Birimian greenstone belts. The N-S trending boundary that transects Burkina Faso and NW Ghana between these two domains seems to represent a first order structure within the WAC.

7.1. Major observations and interpretations:

a) The seismic and gravity data suggest that the West African Craton has a double root of faster 
708 Our thanks go to Kim Hein for improvements to the manuscript, and Stewart Fishwick and 709 anonymous reviewer for numerous helpful suggestions during the review stage. We thank Eric 710 Anderson from the USGS allowed us to see a pre-release version of their results for Mauritania. We 711 acknowledge the West African geological surveys as noted in the text for use of magnetic data, and

712 the Bureau de Gravité Internationale for the gravity grids. We thank Rob Porritt for his additions to 713 FUNCLAB to make this work much easier. MSM would like to thank the IRIS DMC for providing access 714 to the seismic data used in the analysis. We acknowledge the authors who provided digital versions 715 of their LAB and Moho models, either as part of their publications or as a result of specific requests. 716 We wish to gratefully acknowledge AMIRA International and the industry sponsors, as well as AusAid 717 and the ARC Linkage Project LP110100667, for their support of the WAXI project (P934A). We are also appreciative of the contribution of the various Geological Surveys/Department of Mines in West Africa as sponsors in kind of WAXI. Finally, we wish to recognize our WAXI research colleagues from the various Institutions from around the world. 
722

723

724

725

726

727

Abouchami, W., Boher, M., Michard, A. \& Albarede, F. 1990. A major 2.1 Ga event of mafic magmatism in West Africa: an early stage of crustal accretion. Journal of Geophysical Research, 95, 17605-17629.

Afonso, J.C., Schutt, D. 2012. The effects of polybaric partial melting on the density and seismic velocities of mantle restites, Lithos, 134-135, 289-303.

Afonso, J.C., Ranalli, G., Fernandez, M. 2005. Thermal expansivity and elastic properties of the lithospheric mantle: results from mineral physics of composites. Physics of the Earth and Planetary Interiors, 149, 279-306.

Agyei Duodu, J., Loh, G.K., Hirdes, W., Boamah, K.O., Baba, M., Anokwa, Y.M., Asare, C., Brakohiapa, E., Mensah, R.B., Okla, R., Toloczyki, M., Davis, D.W., Gluck, S., 2009. Geological Map of Ghana 1:1,000,000. BGS/GGS, Accra, Ghana/Hannover, Germany.

Allibone, A., Teasdale, J., Cameron, G., Etheridge, M., Uttley, P., Soboh, A., Appiah-Kubi, J., Adanu, A., Arthur, R., Mamphey, J., Odoom, B., Zuta, J., Tsikata, A., Pataye, F., Famiyeh, S., Lamb, E., 2002. Timing and structural controls on gold mineralization at the Bogoso gold mine, Ghana, West Africa. Economic Geology 97, 949-969.

Alpert, L.A., Miller, M.S., Becker, T.W., and Allam, A., 2013, Structure beneath the Alboran from geodynamic flow models and seismic anisotropy: J. Geophys. Res., v. 118, DOI:10.1002/jgrb.50309.

Álvaro, J.J., Vizcaïno, D., 2012. Proterozoic microbial reef complexes and associated hydrothermal mineralizations in the Banfora Cliffs, Burkina Faso. Sediment. Geol. 263-264, 144-156. doi:10.1016/j.sedgeo.2011.11.005

Anahnah, F., Zaldívar, J.G., Chalouan, A., Pedrera, A., Ruano, P., Pous, J., Heise, W., Constan, A.R., Benmakhlouf, M., Carlos, A., Garrido, L., Ahmamou, M.F., Galdeano, C.S. De, Arzate, J., Ibarra, P., Castillo, L.G., Bouregba, N., Corbo, F., Asensio, E., 2011. Deep resistivity cross section of the 

Quaternary volcanism 30, 1-9. doi:10.1029/2010TC002859

Artemieva, I. M. 2009. The continental lithosphere: Reconciling thermal, seismic, and petrologic data, Lithos, 109, 23-46

Bagherbandi, M., Sjöberg, L.E., 2012. Modelling the density contrast and depth of the Moho discontinuity by seismic and gravimetric-isostatic methods with an application to Africa. Journal of African Earth Sciences, 68, 111-120.

Baratoux, L., Metelka, V., Naba, S., Jessell, M.W., Grégoire, M., Ganne, J. 2011. Juvenile Palaeoproterozoic crust evolution during the Eburnean orogeny $(\sim 2.2-2.0 ; G a)$, western Burkina Faso, Precambrian Research, 191, 18-45.

Baratoux, L., Söderlund, U., Ernst, R., Benoit, M., Cournède, C., Jessell, M.W., Perrouty, S., Naba, S. 2014. Petrography and geochemistry of doleritic dykes, eastern part of the Leo-Man Craton, Abs. $25^{\text {th }}$ Colloquium of African Geology, Dar es Salaam.

Bassin, C., Laske, G. and Masters, G., The Current Limits of Resolution for Surface Wave Tomography in North America, EOS Trans AGU, 81, F897, 2000.

Bastow, I.D., Owens, T.J., Helffrich, G., Knapp, J.H., 2007. Spatial and temporal constraints on sources of seismic anisotropy: Evidence from the Scottish highlands. Geophys. Res. Lett. 34, L05305. doi:10.1029/2006GL028911

Bastow, I.D., Pilidou, S., Kendall, J.-M., Stuart, G.W., 2010. Melt-induced seismic anisotropy and magma assisted rifting in Ethiopia: Evidence from surface waves. Geochemistry Geophysics Geosystems 11, Q0AB05.

Bayer, R., Lesquer, A., 1978. Les anomalies gravimétriques de la bordure orientale du craton OuestAfricain: géométrie d’une suture Pan-Africanie. Bulletin de la Société Géologique de France 7, 863-876.

Becker, T.W., Boschi, L., 2002. A comparison of tomographic and geodynamic mantle models. Geochem. Geophys. Geosyst., 3, 10.129/2001GC000168. 
Begg, G.C., Griffin, W.L., Natapov, L.M., O'Reilly, S.Y., Grand, S.P., O'Neill, C.J., Hronsky, J.M. A., Djomani, Y.P., Swain, C.J., Deen, T., Bowden, P., 2009. The lithospheric architecture of Africa: seismic tomography, mantle petrology and tectonic evolution. Geosphere 5, 23-50.

Begg, G.C., Hronsky, J.A.M., Arndt, N.T., Griffin, W.L., O’Reilly, S.Y., Hayward, N. 2010. Lithospheric, Cratonic, and Geodynamic Setting of Ni-Cu-PGE Sulfide Deposits Economic Geology, September-October 2010, v. 105, p. 1057-1070, doi:10.2113/econgeo.105.6.1057

Bessoles, B. 1977. Le Craton Ouest Africain. Geologie de l'Afrique. BRGM Memoire, 88.

Béziat, D., Bourges, F., Debat, P., Lompo, M., Martin, F., Tollon, F., 2000. A Paleoproterozoic ultramafic-mafic assemblage and associated volcanic rocks of the Boromo greenstone belt: Burkina Faso: fractionates originating from island-arc volcanic activity in the West African Craton. Precambrian Research 101, 25-47.

Billa, M., Feybesse, J.-L., Bronner, G., Lerouge, C., Milési, J.-P., Traoré, S., Diaby, S. 1999. Les formations à quartzites rubanés ferrugineux des Monts Nimba et du Simandou : des unités empilées tectoniquement, sur un « soubassement » plutonique Archéen (craton de KénémaMan), lors de l'orogène Eburnéen. C.R. Acad. Sci. Paris, 287-294.

Black, R., Caby, R., Moussine-Pouchkine, A., Bertrand, J. M. L., Boullier, A. M., Fabre, J., Lesquer, A. 1979. Evidence for Precambrian plate tectonics in West Africa. Nature, 278, 223-227.

Black, R., Liégeois, J. P. 1993. Cratons, mobile belts, alkaline rocks and continental lithospheric mantle: the Pan-African testimony. Journal of the Geological Society, London, 150, 89-98.

Block, S., Ganne, J., Baratoux, L., Zeh, A., Parra, L.A., Jessell, M.W., Ailleres, L., Siebenaller, L., Mensah, E. 2015. Petrological and geochronological constraints on lower crust exhumation during Paleoproterozoic (Eburnean) orogeny, NW Ghana, West African craton. Submitted Journal of Metamorphic Geology.

Boher, M., Abouchami, W., Michard, A., Albarede, F., Arndt, N.T. 1992. Crustal growth in west Africa at 2.1 Ga. Journal of Geophysical Research, 97, 345-369. 
Bonhomme, M., 1962. Contribution a l'etude geochronologique de la plate-forme de l'Ouest Africain. Annals de la Faculte des Sciences de Universite de Clermont-Ferrand Geol. Mineral 5, 62.

Bonvalot, S., Villeneuve, M., Albouy, Y. 1991. Interprétation gravimétrique de la Sierra-Leone : mise en évidence d'une suture de collision dans la chaîne panafricaine des Rokelides. C. R. Acad. Sci. Paris, t. 312, Série II, p. 841-848.

Bonvalot, S., Villeneuve, M., Legeley, A., Albouy, Y. 1998. Levé gravimétrique du Sud-Ouest du craton Ouest-Africain. C.R. Acad. Sci. Paris, t. 307, Série II, p. 1863-1868.

Burke, K. Whiteman, A.J. 1973. Uplift, rifting and the breakup of Africa. In Implications of Continental Drift to the Earth Sciences, ed. DH Tarling, SK Runcorn, 2:735-45. London: Academic, In: Burke, K. 2011. Plate Tectonics, the Wilson Cycle, and Mantle Plumes: Geodynamics from the Top. Annual Review of Earth and Planetary Sciences, Vol. 39, pp. 1-29. doi:10.1146/annurevearth-040809-152521

Cassidy, K.F., Champion, D.C. 2004. Crustal evolution of the Yilgarn Craton from Nd isotopes and granite geochronology: implications for metallogeny. In Muhling J et al (eds). SEG 2004, Predictive Mineral Discovery under Cover. Centre for Global Metallogeny, The University of Western Australia Publication 33.

Castaing, C., Billa, M., Milesi, J.P., Thieblemont, D., Le Mentour, J., Egal, E., Donzeau, M., Guerrot, C., Cocherie, A., Chevremont, P., Tegyey, M., Itard, Y., Zida, B., Ouedraogo, I., Kote, S., Kabore, B.E., Ouedraogo, C., Ki, J.C., Zunino, C., 2003. Notice explicative de la carte geologique et miniere du Burkina Faso a 1/1,000,000. BRGM BUMIGEB, p. 147.

Chorlton, L. B. 2007: Generalized Geology of the World: Bedrock Domains and Major Faults in GIS Format; Geological Survey of Canada, Open File 5529, 1 CD-ROM.

Cooper, C.M., Miller, M.S. 2014. Craton formation: Internal structure inherited from closing of the early oceans. Lithosphere, 6 (1), 35-42. doi:10.1130/L321.1 
Davis, D.W., Hirdes, W., Schaltegger, U. and Nunoo, E.A., 1994. U-Pb constraints on deposition and provenance of Birimian and gold-bearing Tarkwaian sediments in Ghana, West Africa. Precambrian Research, 67: 89-107.

Debat, P., Nikiema, S., Mercier, A., Lompo, M., Beziat, D., Bourges, F., Roddaz, M., Salvi, S., Tollon, F., Wenmenga, U., 2003. A new metamorphic constraint for the Eburnean orogeny from Paleoproterozoic formations of the Man shield (Aribinda and Tampelga countries Burkina Faso). Precambrian Research 123, 47-65.

Deen, T.J., Griffin, W.L., Begg, G., O’Reilly, S.Y., Natapov, L.M., Hronsky, J., 2006. Thermal and compositional structure of the subcontinental lithospheric mantle: Derivation from shear wave seismic tomography. Geochemistry Geophys. Geosystems 7, 1-20. doi:10.1029/2005GC001120

Díaz, J., Gallart, J. 2014. Seismic anisotropy from the Variscan core of Iberia to the Western African Craton: New constrains on upper mantle flow at regional scales. Earth and Planetary Science Letters, 394, 48-57. doi:10.1016/j.epsl.2014.03.005

Di Leo, J.F., Wookey, J., Kendall, J.M., and Selby, N.D., 2015. Probing the edge of the West African Craton: A first seismic glimpse from Niger. Geophys. Res. Lett. 42, 1694-1700.

Doumbia, S., Pouclet, A., Kouamelan, A., Peucat, J.J., Vidal, M., Delor, C., 1998. Petrogenesis of juvenile-type Birimian (Paleoproterozoic) granitoids in Cen- voire West Africa: geochemistry and geochronology. Precambrian Research 87, 33-63.

Duffy, T.S., Anderson, D.L., 1989. Seismic velocities in mantle minerals and the mineralogy of the upper mantle. J. Geophys. Res. 94, 1895-1912.

Eagar, K.C., and Fouch, M.J., 2012, FuncLab: A MATLAB Interactive Toolbox for Handling Receiver Function Datasets: Seismo. Res. Lett., v. 83, p. 596-603, 10.1785/gssrl.83.3.596.

Eaton, D.W., Darbyshire, F., Evans, R.L., Grütter, H., Jones, A.G., Yuan, X., 2009. The elusive lithosphere-asthenosphere boundary (LAB) beneath cratons. Lithos 109, 1-22. 
Edwards, R.A., Whitmarsh, R.B., Scrutton, R.A. 1997. The crustal structure across the transform continental margin off Ghana, eastern equatorial Atlantic. Journal of Geophysical Research, 102 (B1), 747. doi:10.1029/96JB02098

Egal, E., Thie, D., Guerrot, C., Adi, C., lliescu, D., Delor, C., Goujou, J., Michel, J., Tegyey, M., Diaby, S., Kolie, P., 2002. Late Eburnean granitization and tectonics along the western and northwestern margin of the Archean Kenema - Man Domain (Guinea, West African Craton). Precambrian Res. 117, 57-84.

Ennih, N., Liégeois, J.-P. 2008. The boundaries of the West African Craton, with special reference to the basement of the Moroccan metacratonic Anti-Atlas belt. In: Ennih, N. \& Liégeois, J.-P. (eds) The Boundaries of the West African Craton. Geological Society, London, Special Publications, $297,1-17,533$ p.

Feybesse JL., Billa M., Guerrot C., Duguey E., Lescuyer JL., Milési JP., Bouchot V.; 2006; The Palaeoproterozoic Ghanaian province: Geodynamic model and ore controls, including regional stress modeling; Precambrian Research 149, 149-196.

Fischer, K.M., Ford, H.A., Abt, D.L., Rychert, C.A., 2010. The lithosphere-asthenosphere boundary: Ann. Rev. Earth Planet. Sci. 38, 551-575.

Fishwick, S. 2010. Surface wave tomography: Imaging of the lithosphere-asthenosphere boundary beneath central and southern Africa? Lithos 120, 63-73

Fishwick, S., Bastow, I.D. 2011. Towards a better understanding of African topography: A review of passive-source seismic studies of the African crust and upper mantle, in Out of Africa: a synopsis of 3.8 Ga of Earth History, (eds. van Hinsbergen, D.J.J., Buiter, S., Torsvik, T.H., Gaina, C. and Webb, S.,) Geol. Soc. Lond. Spec. Pub., 357, 343-371, doi:10.1144/SP357.19.

Fouch, J., Fischer, M., Parmentier, E.M., Wysession, M.E., Clarke, T.J., 2000. Shear wave splitting, continental keels, and patterns 105, 6255-6275. 
871 Foulger, G.R., Panza, G.F., Artemieva, I.M., Bastow, I.D., Cammarano, F., Evans, J.R., Hamilton, W.B., Julian, B.R., Lustrino, M., Thybo, H., Yanovskaya. T.B. 2013. Caveats on tomographic images, Terra Nova, 25, 1365-3121.

874

Fugro Airborne Surveys. 2009. Airborne Geophysical Survey over the Volta River Basin and Keta Basin Geological Interpretation Summary Report, FCR2350/Job. No. 1769. Geological Survey Department, Ghana.

877

Galipp, K., Klemd, R., Hirdes, W., 2003. Metamorphism and geochemistry of the Paleoproterozoic Birimian Sefwi volcanic belt (Ghana, West Africa). Geologisches Jahrbuch D111, 151-191.

Ganne, J., De Andrade, V., Weinberg, R.F., Vidal, O., Dubacq, B., Kagambega, N., Naba, S., Baratoux, L., Jessell, M., Allibon, J., 2011. Modern-style plate subduction preserved in the

Gasquet, D., Barbey, P., Adou, M., Paquette, J.L., 2003. Structure Sr-Nd isotope geochemistry and zircon U-Pb geochronology of the granitoids of the Dabakala area (Cote d'Ivoire): evidence for a 2.3 Ga crustal growth event in the Palaeoproterozoic of West Africa? Precambrian Research 127, 329-354.

Grand, S., 2002. Mantle shear-wave tomography and the fate of subducted slabs. Philosophical Transactions Royal Society of London, A360, 2475-2491.

Griffin, W.L., Begg, G.C., O’Reilly, S.Y., 2013. Continental-root control on the genesis of magmatic ore deposits. Nat. Geosci. 6, 905-910. doi:10.1038/ngeo1954

Griffin, W.L., O’Reilly, S.Y., Afonso, J.C., Begg, G.C., 2008. The Composition and Evolution of Lithospheric Mantle: a Re-evaluation and its Tectonic Implications. J. Petrol. 50, 1185-1204. doi:10.1093/petrology/egn033

Hammond, W.C., Humphreys, E.D. 2000. Upper mantle seismic wave velocity: Effects of realistic partial melt geometries, Journal of Geophysical Research: Solid Earth, 105, B5, 2156-2202. Doi :10.1029/2000JB900041 
Hansen, S.E., Nyblade, A. a., Benoit, M.H., 2012. Mantle structure beneath Africa and Arabia from adaptively parameterized P-wave tomography: Implications for the origin of Cenozoic AfroArabian tectonism. Earth Planet. Sci. Lett. 319-320, 23-34. doi:10.1016/j.epsl.2011.12.023

Hartley, R., Watts, A.B., Fairhead, J.D. 1996. Isostasy of Africa, 137(I 996), 1-18. Earth and Planetary Science Letters 137, 1- 18.

Hartley, R., Watts, A.B., Fairhead. J.D. 1996. Isostasy of Africa. Earth and Planetary Science Letters, $137,1-18$

Hein, K.A.A., 2010. Succession of structural events in the Goren greenstone belt (Burkina Faso): implications for West African tectonics. Journal of African Earth Sciences 56, 83-94.

Heine, C. 2007. Formation and Evolution of intracontinental basins, PhD Thesis, School of Geosciences, The University of Sydney, Australia, unpublished.

Hemant, K., Maus, S. 2005. Geological modeling of the new CHAMP magnetic anomaly maps using a geographical information system technique. Journal of Geophysical Research 110, B12103.

Hirdes, W., Davis, D.W., Ludtke, G., Konan, G., 1996. Two generations of Birimian (Paleoproterozoic) volcanic belts in northeastern Cote d'Ivoire (West Africa): consequences for the 'Birimian controversy. Precambrian Research 80, 173-191.

Jessell, M.W., Prince O. Amponsah, Lenka Baratoux, Daniel K. Asiedu, Geoffrey K. Loh, Jérôme Ganne. 2012. Crustal-scale transcurrent shearing in the Paleoproterozoic Sefwi-SunyaniComoé region, West Africa, Precambrian Research, 212-213, 155-168.

Jessell, M.W., Santoul, J., Baratoux, L., Youbi, N., Ernst, R.E., Metelka, V., Miller, J., Perrouty, S. 2015. An updated map of West African mafic dykes. In press. J. Afr. Earth Sci. doi: 10.1016/j.jafrearsci.2015.01.007Jessell, M.W., Boamah, K., Duodu, J.A., Ley-Cooper, Y. 2015. Geophysical evidence for a major paleochannel within the Obosum Group of the Volta Basin, Northern Region, Ghana. Submitted J. Afr. Earth Sci. http://dx.doi.org/10.1016/j.jafrearsci.2015.04.007 
John, T., Klemd, R., Hirdes, W., Loh, G., 1999. The metamorphic evolution of the Paleoproterozoic (Birimian) volcanic Ashanti belt (Ghana West Africa). Precambrian Research 98, 11-30.

Jones, A.G., Kiyan, D., Fullea,J., Ledo, J., Queralt, P., Marcuello, A., Siniscalchi, A., Romano, G. 2012. Comment on "Deep resistivity cross section of the intraplate Atlas Mountains (NW Africa): New evidence of anomalous mantle and related Quaternary volcanism" Tectonics, 31, doi:10.1029/2011TC003051

Jordan, T.H. 1975. The continental tectosphere. Reviews of Geophysics and Space Physics 13, 1-12.

Jordan, T.H. 1978. Composition and development of the continental tectosphere. Nature 274, 544548.

Karato, S.-I., 1995. Effects of water on seismic wave velocities in the upper mantle. Proc. Jpn. Acad. $71(B), 61-66$.

Kendall, J.-M. (1994), Teleseismic arrivals at a mid-ocean ridge: Effects of melt and anisotropy, Geophys. Res. Lett., 21, 301-304.

Kribek, B., Sykorova, I., Machovic, V., Laufek, F., 2008. Graphitization of organic matter and fluiddeposited graphite in Palaeoproterozoic (Birimian) black shales of the Kaya-Goren greenstone belt (Burkina Faso West Africa). Journal of Metamorphic Geology 26, 937-958.

Kutu, J.M. 2013. Seismic and Tectonic Correspondence of Major Earthquake Regions in Southern Ghana with Mid-Atlantic Transform-Fracture Zones. International Journal of Geosciences, 4, 1326-1332, doi:dx.doi.org/10.4236/ijg.2013.410128

Langston, C.A., 1977. The effect of planar dipping structure on source and receiver responses for constant ray parameter, Bull. Seismol. Soc. Am., 67, 1029-1050.

Laske, G., Masters, G., Ma, Z. and Pasyanos, M. 2013. Update on CRUST1.0 - A 1-degree Global Model of Earth's Crust, Geophys. Res. Abstracts, 15, Abstract EGU2013-2658.

Le Pape, F., Jones, A.G., Jessell, M.W., Hogg, C., Siebenaller, L., Touré, A., Boren, G., Ouiya, P., Mahamud, A. 2014. Preliminary 2D results from a Magnetotelluric survey crossing Burkina 

Weimar, Germany, August 24-30, 2014.

948

949

950

951

952

953

954

955

956

957

958

959

960

961

962

963

964

965

966

967

968

969

970

971

Lebedev, S. van der Hilst, R. D. 2008. Global uppermantle tomography with the automated multimode inversion of surface and S-wave forms. Geophysical Journal International 173, 505-518.

Ledo, J., Jones, A.G., Siniscalchi, A., Campanyà, J., Kiyan, D., Romano, G., Rouai, M., 2011. Electrical signature of modern and ancient tectonic processes in the crust of the Atlas Mountains of Morocco. Phys. Earth Planet. Inter. 185, 82-88. doi:10.1016/j.pepi.2011.01.008

Lesquer, A., Beltrao, J. F., Abreu, F. A. M. O. 1984. Proterozoic Links between Northeastern Brazil and West Africa: A Plate Tectonic Model based on Gravity Data. Tectonophysics, 110, 9-26.

Leube, A., Hirdes, W., Mauer, R., Kesse, Rohstoffe, G.O., 1990. The Early Proterozoic Birimian Supergroup of Ghana and Some Aspects of its Associated Gold Mineralization Precambrian Research, 46, 139-165.

Li, B., Kung, J., Liebermann. R.C. 2004. Modern techniques in measuring elasticity of Earth materials at high pressure and high temperature using ultrasonic interferometry in conjunction with synchrotron X-radiation in multi-anvil apparatus, Physics of the Earth and Planetary Interiors, 143-144, 559-574, doi:10.1016/j.pepi.2003.09.020.

Long, M.D., Becker, T.W. 2010. Mantle dynamics and seismic anisotropy. Earth and Planetary Science Letters 297, 341-354.

Ludtke, G., Hirdes, W., Konan, G., Kone, Y., N’da, D., Traore, Y., Zamble, Z., 1999. Geologie de la region Haute Comoe Sud-feuilles Dabakala (2b, d et 4b, d). Direction de la Geologie Abidjan Bulletin, 176.

Maus, S., Barckhausen, U., Berkenbosch, H., Bournas, N., Brozena, J., Childers, V., Dostaler, F., Fairhead, J.D., Finn, C., Von Frese, R.R.B., Gaina, C., Golynsky, S., Kucks, R., Lühr, H., Milligan, P., Mogren, S., Müller, R.D., Olesen, O., Pilkington, M., Saltus, R., Schreckenberger, B., Thébault, E., Caratori Tontini, F., 2009. EMAG2: A 2-arc min resolution Earth Magnetic 
Anomaly Grid compiled from satellite, airborne, and marine magnetic measurements. Geochemistry Geophysics Geosystems 10(8), Q08005. doi:10.1029/2009GC002471

Metelka, V., Baratoux, L., Naba, S., Jessell, W.M., 2011 A geophysically constrained litho-structural analysis of the Eburnean greenstone belts and associated granitoid domains, western Burkina Faso. Precambrian Research, doi:10.1016/j.precamres.2011.08.002.

Meyer, F.M., Kolb, J., Sakellaris, G.A., Gerdes, A. 2006. New ages from the Mauritanides Belt: recognition of Archean IOCG mineralization at Guelb Moghrein, Mauritania. Terra Nova, 18(5), 345-352. doi:10.1111/j.1365-3121.2006.00698.x

Mickus, K., 2008. Regional gravity analysis of Burkina Faso: Implications for the location of metallic ore deposits. J. African Earth Sci. 50, 55-66. doi:10.1016/j.jafrearsci.2007.09.016

Milesi, J.P., Feybesse, J.L., Ledru, P., Dommanget, A., Ouedraogo, M.F., Marcoux, E., Prost, A., Vinchon, C., Sylvain, J.P., Johan, V., Tegyey, M., Calvez, J.Y., Lagny, P., 1989. Mineralisations auriferes de l'Afrique de l'ouest, leurs relations avec l'evolution litho-structurale au Proterozoique inferieur Carte geologique au 1/2,000,000. Chronique de la recherche miniere 497, 3-98.

Milesi, J.-P., Ledru, P., Feybesse, J.-L., Dommanget, A., Marcoux, E., 1992. Early Proterozoic ore deposits and tectonics of the Birimian orogenic belt West Africa. Precambrian Research 58, 305-344.

Miller, M.S., Allam, A.A., Becker, T.W., Di Leo, J.F., Wookey, J. 2013. Constraints on the tectonic evolution of the westernmost Mediterranean and northwestern Africa from shear wave splitting analysis. Earth and Planetary Science Letters, 375, 234-243. doi:10.1016/j.epsl.2013.05.036.

Miller, M.S., Becker, T.W 2014. Reactivated lithospheric-scale discontinuities localize dynamic uplift of the Moroccan Atlas Mountains: Geology, v. 42, p. 35-38, 10.1130/g34959.1. 
Moidaki, M.D., 2014. Double layer anisotropy beneath the New Madrid seismic zone and adjacent areas: insights from teleseismic shear wave splitting. Res. Geophys. 3, 3. doi:10.4081/rg.2013.e3

Mooney, Laske and Masters, Crust 5.1: a global crustal model at 5x5 degrees, Journal of Geophysical Research, 103, 727-747, 1998

Moussine-Pouchkine, A., Bertrand-Sarfati, J. 1997. Tectonosedimentary subdivisions in the Neoproterozoic to early Cambrian cover of the Taoudenni Basin (Algeria-Mauritania-Mali). Journal of African Earth Science, 7, 57-75.

Naba, S., Lompo, M., Debat, P., Bouchez, J.L., Beziat, D., 2004. Structure and emplacement model for late-orogenic Paleoproterozoic granitoids: the Tenkodogo-Yamba elongate pluton (Eastern Burkina Faso). Journal of African Earth Sciences 38, 41-57.

Nataf, H.-C., Ricard, Y., 1996. 3SMAC: an a priori tomographic model of the upper mantle based on geophysical modeling. Physics of the Earth and Planetary Interiors 95, 101-122.

Oberthur, T., Vetter, U., Davis, D.W., Amanor, J.A., 1998. Age constraints on gold mineralization and Paleoproterozoic crustal evolution in the Ashanti belt of southern Ghana. Precambrian Research 89, 129-143.

Obrebski, M., Kiselev, S., Vinnik, L., Montagner, J.-P., 2010. Anisotropic stratification beneath Africa from joint inversion of SKS and P receiver functions. Journal of Geophysical Research 115, B09313.

Parra-Avila, L.A. 2015. 4D Evolution of the Paleoproterozoic Baoulé-Mossi Domain of the West African Craton, PhD Thesis (submitted), The University of Western Australia.

Pasyanos, M.E. \& Nyblade, A.A., 2007. A top to bottom lithospheric study of Africa and Arabia, Tectonophysics, 444, 27-44.

Pasyanos, M.E. 2010. Lithospheric Thickness Modeled from Long Period Surface Wave Dispersion. Tectonophysics, 481, 38-50. 
Pasyanos, M.E., Masters, T.G., Laske, G., \& Zhitu, M. 2014. LITHO1.0: An updated crust and lithospheric model of the Earth. J. Geophys. Res. Solid Earth, 119, 2153-2173. doi:10.1002/2013JB010626.

Pavlis, N.K., Holmes, S.A., Kenyon, S.C., \& Factor, J.K. 2012. The development and evaluation of the Earth Gravitational Model 2008 (EGM2008). Journal of Geophysical Research, 117(B4), B04406. doi:10.1029/2011JB008916

Pérez-Gussinyé, M., Metois, M., Fernandez, M., Vergés, J., Fullea, J. \& Lowry, A. R. 2009. Effective elastic thickness of Africa and its relationship to other proxies for lithospheric structure and surface tectonics. Earth and Planetary Science Letters 287, 152-167.

Perrouty, S., Aillères, L., Jessell M., Baratoux, L., Bourassa, Y. 2012 Revised Eburnean Geodynamic Evolution of the Gold-rich Southern Ashanti Belt, Ghana, with new Field and Geophysical Evidence of pre-Tarkwaian Deformation. Precambrian Research, 204, 12-39.Perrouty, S., Jessell, M.W., Bourassa, Y., Miller, J., Apau, D., Siebenaller, L., Velásquez, G., Baratoux, L., Aillères, L., Béziat, D., Salvi, S. 2015. The Wassa mine: a poly-deformed orogenic gold system in southwest Ghana - Implications for regional exploration. In press J. Afr. Earth Sci.

Pons, J., Barbey, P., Dupuis, D., Leger, J.M., 1995. Mechanisms of pluton emplacement and structural evolution of a 2.1 Ga juvenile continental crust: the Birimian of southwestern Niger. Precambrian Research 70, 281-301.

Pouclet, A., Vidal, M., Delor, C., Simeon, Y.,M., Arlic, G. 1996. Le volcanisme birimien du nord-est de la Côte-d'Ivoire, mise en évidence de deux phases volcano-tectoniques distinctes dans l'évolution géodynamique du Paléoprotérozoïque. Bull. Soc. Geol France, 167, 529-541.

Poudjom Djomani, Y.H., O’Reilly, S.Y., Griffin, W.L., Natapov, L.M., Erinchek, Y., Hronsky, J. 2003. Upper mantle structure beneath eastern Siberia: evidence from gravity modeling and mantle petrology. Geochemistry, Geophysics, Geosystems 4 (7), 1066, doi:10.1029/2002GC000429.

Priestley, K. and F. Tilmann, 2009, "Relationship between the upper mantle high velocity seismic lid and the continental lithosphere." Lithos, 109 112-124. doi:10.1016/j.lithos.2008.10.021. 
1050

1051

1052

1053

1054

1055

1056

1057

1058

1059

1060

1061

1062

1063

1064

1065

1066

1067

1068

Reichelt, R. 1971. Géologie du Gourma (Afrique occidentale), un seuil et un bassin du Précambrien supérieur, Mém. BRGM n॰53.

Rawlinson, N., Fishwick, S., 2012. Seismic structure of the southeast Australian lithosphere from surface and body wave tomography. Tectonophysics 572-573, 111-122. doi:10.1016/j.tecto.2011.11.016

Reguzzoni, M., Sampietro, D., \& Sanso, F. 2013. Global Moho from the combination of the CRUST2.0 model and GOCE data. Geophysical Journal International, 195(1), 222-237. doi:10.1093/gji/ggt247

Reid, A.B., Ebbing, J., Webb, S.J., 2012. Comment on "A crustal thickness map of Africa derived from a global gravity field model using Euler deconvolution" by Getachew E. Tedla, M. van der Meijde, A. A. Nyblade and F. D. van der Meer. Geophysical Journal International 189, 12171222.

Ritz, M. 1983. The distribution of electric conductivity on the eastern border of the West African craton (Republic of Niger). Geophys. J.R. Astron. Soc., 73, 475-488.

Ritz, M. 1984. Inhomogeneous Structure of the Senegal Lithosphere from Deep Magnetotelluric Soundings. Journal of Geophysical Research. 89, NO. B13, 11,317-11,331.

Ritz, M. Robineau, B., Vassal, J., Bellion, Y., Dukhan. M. 1989. Structures of the West African Craton Margin across Southern Mauritania inferred from a 450-Km Geoelectrical Profile. Geophysical Research Letters, 16, 283-286.

Ritz, M., Robineau, B. 1988. Tectonic Interpretation of Electrical Structures beneath the West African Craton Edge in Eastern Senegal, American Journal of Science, 288, 756-776.

Rondenay, S. 2009. Upper Mantle Imaging with Array Recordings of Converted and Scattered Teleseismic Waves, Surveys in Geophysics, 30, 377-405.

Rooney, A.D., Selby, D., Houzay, J.-P., Renne, P.R. 2010. Re-Os geochronology of a Mesoproterozoic sedimentary succession, Taoudeni basin, Mauritania: Implications for basin wide correlations 
and Re-Os organic-rich sediments systematic. Earth and Planetary Science Letters, v. 289, no. 3-4, pp. 486-496.

Roussel, J., Lesquer, A. 1991. Geophysics and the Crustal Structure of West Africa. In (Eds.) Dallmeyer, R.D., Lécorché, J.P. The West African Orogens and Circum-Atlantic Correlatives, IGCP-Project 233 1991, pp 9-28, 405p, Springer-Verlag, Berlin Heidelberg.

Salah, M. K. 2012. A seismological evidence for the northwestward movement of Africa with respect to Iberia from shear-wave splitting. Geoscience Frontiers, 3(5), 681-696. doi:10.1016/j.gsf.2012.01.005

Schaeffer, A.J., Lebedev, S. 2013. Global shear speed structure of the upper mantle and transition zone, Geophys. J. Int., 1-33, doi: 10.1093/gji/ggt095

Schofield, D. I., \& Gillespie, M. R. 2007. A tectonic interpretation of "Eburnean terrane" outliers in the Reguibat Shield, Mauritania. Journal of African Earth Sciences, 49 (4-5), 179-186. doi:10.1016/j.jafrearsci.2007.08.006

Schofield, D.I., Gillespie, M.R., 2007. A tectonic interpretation of "Eburnean terrane" outliers in the Reguibat Shield, Mauritania. J. African Earth Sci. 49, 179-186. doi:10.1016/j.jafrearsci.2007.08.006

Sebai, A., Stutzmann, E., Montagner, J.-P., Sicilia, D. \& Beucler, E. 2006. Anisotropic structure of the African upper mantle from Rayleigh and Love wave tomography. Physics of the Earth and Planetary Interiors, 155, 48-62.

Sestini, G., 1973. Sedimentology of a Paleoplacer: the gold-bearing Tarkwaian of Ghana. International Union of Geological Sciences, Series A 3, 275-305.

Siegfried, P., De Kock, G.S., Clarke, B., Agenbacht, A., Delor, C., Van Rooyen, R.C., 2009. Geological map explanation - map sheet 0903D (1:100 000). Mining Sector Support Programme. CGS, BRGM, Geoman, GSD, Accra.

Simmons, N. a., Forte, A.M., Boschi, L., Grand, S.P., 2010. GyPSuM: A joint tomographic model of mantle density and seismic wave speeds. Journal of Geophysical Research 115, 1-24. 
Snyder, D.B., Lockhart, G., 2009. Does seismically anisotropic subcontinental mantle lithosphere require metasomatic wehrlite-pyroxenite dyke stockworks? Lithos 112, 961-965.

Spieker, K., Ingo, W., Thomas, C., Harnafi, M., \& Moudnib, L. El. 2014. Crustal and upper-mantle structure beneath the western Atlas Mountains in SW Morocco derived from receiver functions, 1474-1485. doi:10.1093/gji/ggu216

Teal, D.J., Kah, L.C., 2005. Using C-isotopes to constrain interbasinal stratigraphic correlations, Mesoproterozoic Atar Group, Mauritania. Geological Society of America, Abstracts with Programs 37, 45.

Tedla, G.E., van der Meijde, M., Nyblade, A. A., van der Meer, F. D. 2011: A crustal thickness map of Africa derived from a global gravity field model using Euler deconvolution. Geophysical Journal International 18, 1-9 (dio http://dx.doi.org/10.1111/j.1365-246X.2011.05140.x)

Tidjani, M., Affaton, P., Louis, P., Lesquer, A., Socohou, A., Caby, R., 1993. Gravity characteristics of the northern part of the Dahomeyides: continental aggregation-collision orogen and gravity smoothing in the Pan-African (600 $\pm 100 \mathrm{Ma}$ ). Journal of African Earth Sciences 17, 203-211.

Toft, P.B., Haggerty, S. E. 1986. A Remanent and Induced Magnetization Model of Magsat Vector Anomalies over the West African Craton. JGR, 13(4), 341-344.

Toft, P.B., Taylor, P. T., Arkani-Hamed, J., \& Haggerty, S. E. 1992 Interpretation of satellite magnetic anomalies over the West African Craton. Tectonophysics, 212(1-2), 21-32. doi:10.1016/00401951(92)90137-U

Tshibubudze, A., Hein, K. A. A., \& Marquis, P. 2009. The Markoye Shear Zone in NE Burkina Faso. Journal of African Earth Sciences, 55(5), 245-256. doi:10.1016/j.jafrearsci.2009.04.009

Tshibubudze, A., Hein, K.A.A., 2013b. Structural setting of gold deposits in the Oudalan-Gorouol volcano-sedimentary belt east of the Markoye Shear Zone, West African craton. Journal of African Earth Sciences 80, 31-47. http://dx.doi.org/10.1016/j.jafrearsci.2012.11.010; ISSN $1464-343 X$ 
Tshibubudze, A., Hein, K.A.A., Peters, L.F.H., Woolfe, A.J., \& McCuaig, T.C. 2013a. Oldest U-Pb Crystallisation Age for the West African Craton fFrom the Oudalan-Gorouol Belt of Burkina Faso. South African Journal of Geology, 116(1), 169-181. doi:10.2113/gssajg.116.1.169

Tugume, F., Nyblade, A., Julià, J., van der Meijde, M. 2013. Precambrian crustal structure in Africa and Arabia: Evidence lacking for secular variation, Tectonophysics, 609, 250-266.

van der Meijde, M., Nyblade, A.A. 2014. Reply to "Comment on 'A crustal thickness map of Africa derived from a global gravity field model using Euler deconvolution"', Geophys. J. Int. , 196, 96-99.

Villeneuve, M., 2005. Paleozoic basins in West Africa and the Mauritanide thrust belt. J. African Earth Sci. 43, 166-195. doi:10.1016/j.jafrearsci.2005.07.012

Vinnik, L.P., 1977. Detection of waves converted from P to SV in the mantle, Phys. Earth Planet. Inter., 15, 39-45.

Whitelaw, O.A.L., 1929. The geological and mining features of the Tarkwa-Abosso Goldfield. Gold Coast Geological Survey Memoir 1, 1-45.

Wüstefeld, A., Bokelmann, G., Barruol, G., Montagner, J.-P., 2009. Identifying global seismic anisotropy patterns by correlating shear-wave splitting and surface-wave data. Phys. Earth Planet. Inter. 176, 198-212. doi:10.1016/j.pepi.2009.05.006

Zhu, L., Kanamori, H., 2000, Moho depth variation in southern California from teleseismic receiver functions: J. Geophys. Res., v. 105, p. 2969-2980. 
Figure 1. Map of West Africa showing the ages of the major terranes, modified from the Geological Survey of Canada 1:35M map of the world (Chorlton, 2007). The approximate limits of West African Craton today is indicated by a thick dashed line (after Ennih \& Liegeois, 2008). We also present he interpreted location of the craton margin at $2050 \mathrm{Ma}$, at or immediately below the Moho (thin dashed line), in an attempt to "see through" later reworking of its margins. Two-letter country codes: BF: Burkina Faso; Cl: Côte d'Ivoire; DZ: Algeria; GH: Ghana; GM: The Gambia; GN: Guinea; GW: Guinea Bissau; LR: Liberia; MA: Morocco; ML: Mali; MR: Mauritania; NE: Niger; SL: Sierra Leone; SN: Senegal; and TO: Togo.

Figure 2. Tomographic image S-wave velocity anomalies ( $\delta \mathrm{Vs})$ of West Africa, at five depth intervals using an updated model generated by Steve Grand (2011 model, methodology outlined in Grand, 2002) at the University of Texas, Austin, USA, and reprocessed as described in Begg et al., 2009. Reference velocity is shown for each depth interval. Red to white colours denote Vs much faster than the starting model; blue-green colours show Vs much slower than the starting model. Different color scale ranges are used for each level, (see Begg et al., 2009 for discussion). The 0-100 km and 100-175 km images show a single large fast Vs anomaly over the WAC, whereas the $175-250 \mathrm{~km}, 250$ $325 \mathrm{~km}$ and $325-400 \mathrm{~km}$ images show two distinct high velocity zones, one centred just south of the Reguibat Inlier in northern Mauritania and Mali, and the other beneath the Ghana-Côte d'Ivoire border. The edges of higher $\delta \mathrm{Vs}$ zones in the deeper depth intervals are essentially coincident with the modern WAC margins, whereas in the two shallowest depth intervals the high $\delta \mathrm{Vs}$ zones extends considerably beyond the margin in the south-eastern part of the craton.

Figure 3. Horizontal slices through Vs models at nearest available depth to $180 \mathrm{~km}$. a) Sebai et al., 2006, surface wave inversion for $180 \mathrm{~km}$ depth at $4^{\circ}$ spatial resolution;

b) Simmons et al., 2010, body wave inversion for $175-250 \mathrm{~km}$ depth interval at $1^{\circ}$ spatial resolution; c) Fishwick, 2010, 
surface wave inversion for $175 \mathrm{~km}$ depth at $0.5^{\circ}$ spatial resolution; d) This paper (reprocessing of Grand, 2011 models), body wave inversion for 175-250 depth interval at $1^{\circ}$ spatial resolution and e) Schaeffer \& Lebedev, 2013, joint surface and body wave inversion for $200 \mathrm{~km}$ depth at $0.25^{\circ}$ spatial resolution.

Figure 4. Imaging the LAB and other SCLM features at the scale of the WAC. a) Estimates of lithospheric thickness derived from $\mathrm{S}$ wave data, showing a single elongate root progressively widening to the south (after Priestley and Tilmann, 2009). b) Lithospheric thickness for West Africa based on the tomographic model of Fishwick (2010). This model suggests that the LAB under West Africa is divided into two distinct roots (after Fishwick \& Bastow, 2011). c) Estimates of lithospheric thickness derived from the modelling of long-period surface waves, and again suggesting that the LAB is divided into two distinct roots (after Pasyanos, 2010). d) Pasyanos et al., 2014. Litho 1.0. model showing two main roots with a third centred under the Mali-Guinea border.

Figure 5. Comparison of different Moho and LAB models for the WAC. a) Map showing location of $\mathrm{S}$ and $\mathrm{P}$ receiver function picks from Miller and Becker (2014, PRF, inverted triangles); Spieker et al. (2014, PRF, triangles) and Cooper and Miller (2014, SRF circles; PRF squares), Di Leo et al, 2015 (PRF, diamond) as well as location of an arbitrary NW-SE profile (dashed line A-A'). b) Different models of the depth to LAB along an arbitrary NW-SE profile A-A' for models of Priestley and Tilmann, 2009 (P\&T); Fishwick and Bastow, 2011 (F\&B); Pasyanos, 2010 and Paysanos et al., 2014). c) Scatterplot comparing depth to $L A B$ models versus receiver function $L A B$ depth estimates. d) Comparison between different models of the Moho along an arbitrary NW-SE profile (models of Nataf \& Ricard, 1996; Pasyanos and Nyblade, 2007; Tedla et al., 2011; Bagherbandi and Sjoberg, 2012; Tugume et al., 2013; Reguzzoni et al., 2013; Laske et al., 2013 and Pasyanos et al., 2014). e) Scatterplot comparing same depth to Moho models versus new $\mathrm{P}$ wave receiver function Moho depth estimates from Table 1. 
Figure 6. Seismic anisotropy under West Africa showing spatial variation within depth intervals and

1195

1196

1197

1198

1199

1200

1201

1202

1203

1204

1205

1206

1207

1208

1209

1210

1211

1212

1213

1214

1215

1216

1217

1218 vertical stratification of anisotropy directions and magnitudes. Shear wave azimuthal anisotropy Vs fast direction vectors at depths of a) $80 \mathrm{~km}$ (red), b) $180 \mathrm{~km}$ (green) and c) $280 \mathrm{~km}$ (blue), from Sebai et al. (2006).

Figure 7. Crustal thickness estimates. The thickness models shown as a-h all use the same colour scale, clipped between $20 \& 50 \mathrm{~km}$ to highlight the variations. a) $2^{\circ}$ spatial resolution 3 SMAC Moho model of Nataf \& Ricard (1996). b) $1^{\circ}$ spatial resolution Moho model based on seismic refraction data at $1^{\circ}$ resolution, data from Laske et al. (2013; Crust 1.0$)$. c) $1^{\circ}$ spatial resolution model based on Surface Wave Tomography, data from Pasyanos \& Nyblade (2007). d) $0.225^{\circ}$ spatial resolution model based on 3-D Euler deconvolution, data from Tedla et al. (2011). e) $2^{\circ}$ spatial resolution model of Bagherbandi \& Sjoberg (2012) from seismic and gravimetric-isostatic methods (data from). f) $0.25^{\circ}$ spatial resolution Moho model based on gravity inversion (data from Tugume et al 2013). g) $0.5^{\circ}$ spatial resolution model showing on data from Reguzzoni et al. (2013) from GOCE gravity data. h) $0.16^{\circ}$ spatial resolution Litho 1.0 model of Pasyanos et al., (2014).

Figure 8. $>30 \mathrm{~km}$ wavelength potential field data. a) NGA/BGI Bouguer Gravity Anomaly image for West Africa. Processing consists of taking the First Vertical Derivative of the $30 \mathrm{~km}$ upward continuation of data (displayed in colour) and overlaying the Automatic Gain Control image of the same data (as grayscale). b) Magnetic Anomaly image for West Africa based on a compilation of EMAG2 and more recent airborne surveys. Processing consists of taking the First Vertical Derivative of the $30 \mathrm{~km}$ upward continuation of data (displayed in colour) and overlaying the Automatic Gain Control image of the same data (as grayscale). White areas show data gaps.

Figure 9. Interpreted structure map for West Africa based on manual joint interpretation of mediumwavelength gravity and magnetic data. a) Raw interpretations without age attribution. b) Structures attributed to each age group, with attributions based on correlations with other geological and geophysical datasets. 
Figure 10. Interpreted structure map for West Africa based on manual interpretation of mediumwavelength gravity and magnetic data, separated into notional age groups.

Figure 11. a) Comparisons between different geophysically-based datasets for West Africa. a) Comparison between $>500 \mathrm{~km}$ gravity anomalies and Fishwick (2010) lithosphere thickness model (contour colours removed to enhance contrast, see Fig. $4 \mathrm{~b}$ for depth information). NE-SW gravity high running through Mali can be explained by coincident shallowing of base of lithosphere. b) Comparison between $>500 \mathrm{~km}$ gravity anomalies and mid-crustal features assigned to Archean age showing coincidence of local gravity highs along the continental margin high. c) Comparison of the $175-250 \mathrm{~km} \delta$ Vs slice from Fig. 3 and the Free Air gravity anomalies showing the coincidence between the lower Vs zone between the two roots to the WAC and a pair of ENE-oriented pair of gravity highs in central Mali. d) Comparison between $80 \mathrm{~km}$ depth Vs fast directions (Sebai et al., 2006) and mafic dyke orientations as mapped by Jessell et al. (2015) showing coincidence of main orientations in Mauritania, Sierra Leone, Liberia and south-eastern Ghana. e) Comparison between $180 \mathrm{~km}$ depth Vs fast directions (Sebai et al., 2006) and Grand $\delta$ Vs model at $180 \mathrm{~km}$ showing division of SCLM into two zones of high dVs coincides with change in orientation of, and local magnitude (lower) of, seismic anisotropy.

Figure 12. 3D model of the West African Craton. Datasets referred to in this paper placed in their 3D position within a craton-scale 3D model using Gocad to visualise the spatial relationships between different features. All models have $x 5$ vertical exaggeration. a) View from above of mid-crustal features interpreted from gravity and magnetic data and Moho surface as calculated by Pasyanos \& Nybade, 2007) b) View from south-west showing $500 \mathrm{~km}$ wavelength gravity and LAB surface as calculated by Fishwick, 2010. C) Moho (Pasyanos \& Nyblade, 2007) contoured with horizontal gradient in Moho depth together with LAB (Fishwick, 2010). 


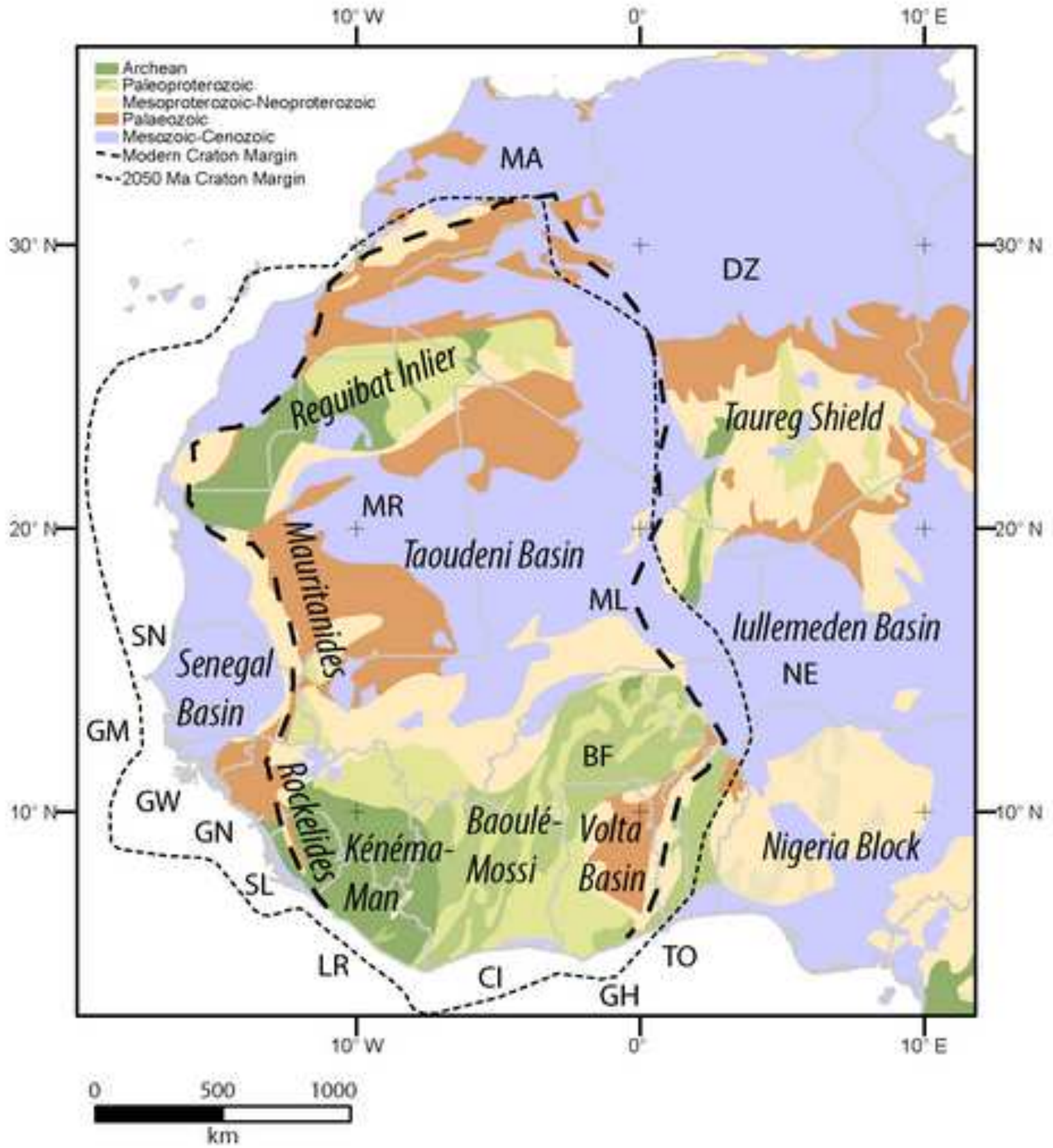

Figure 1 

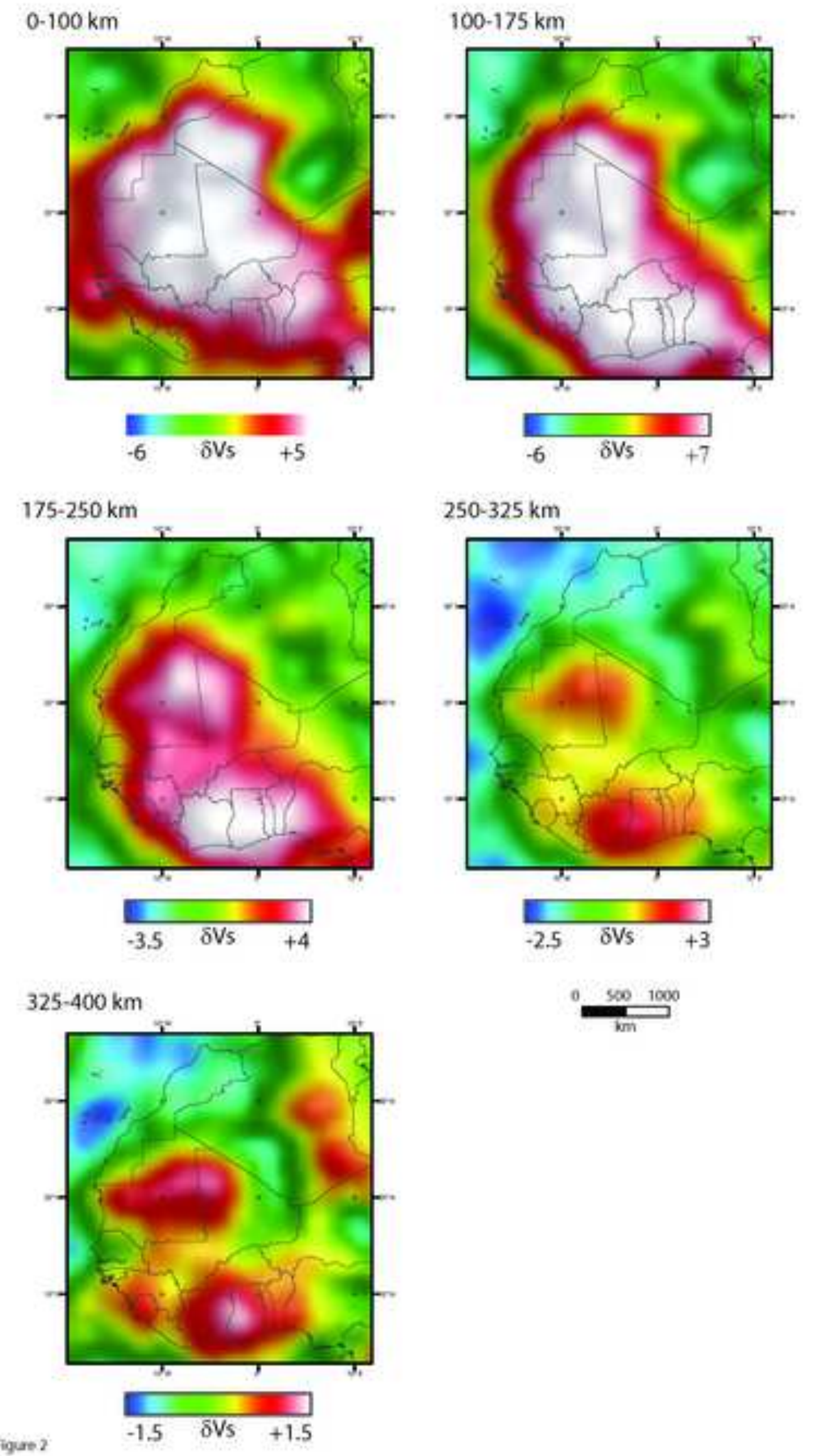

Figuan? 

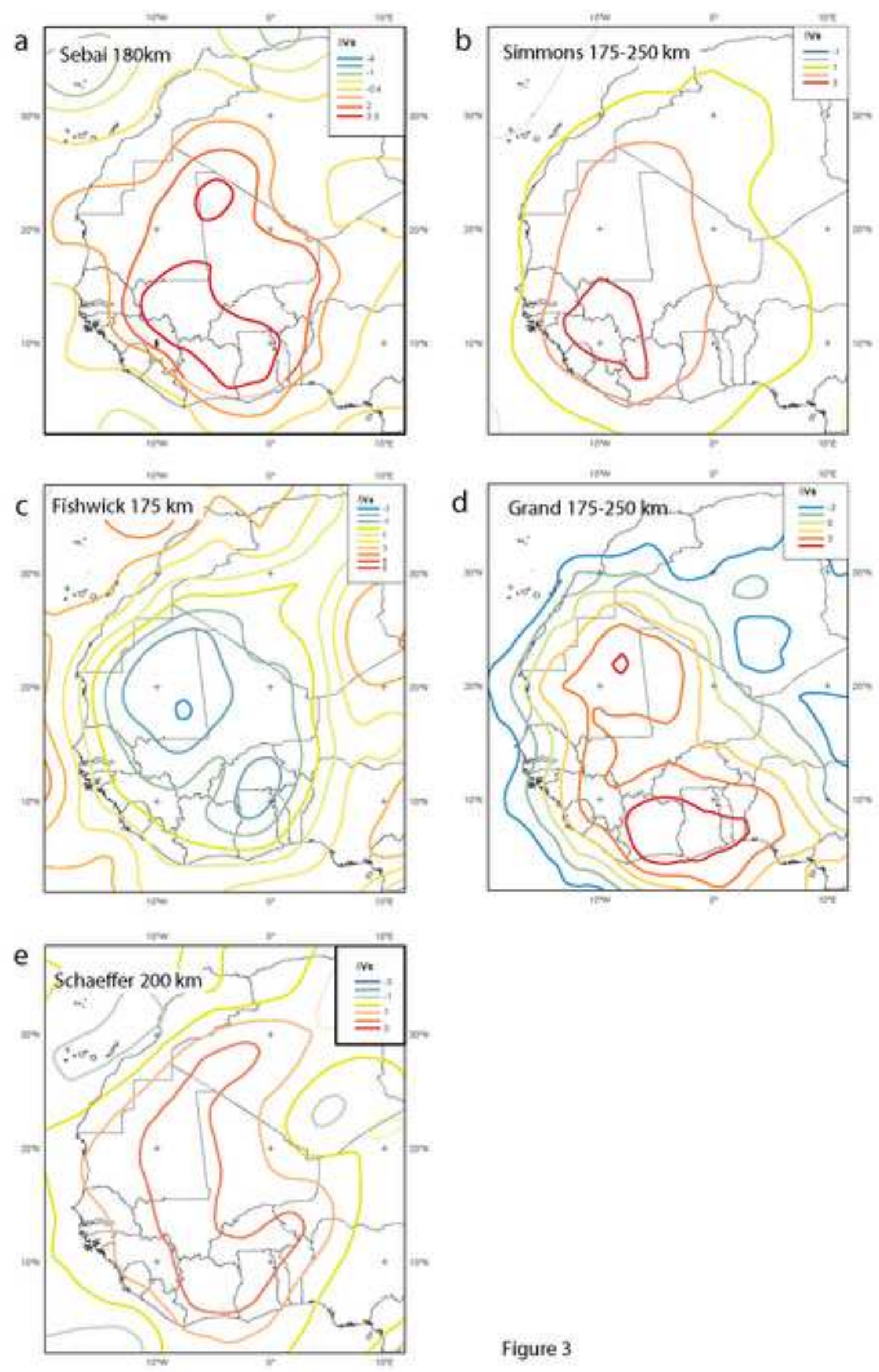

Figure 3 

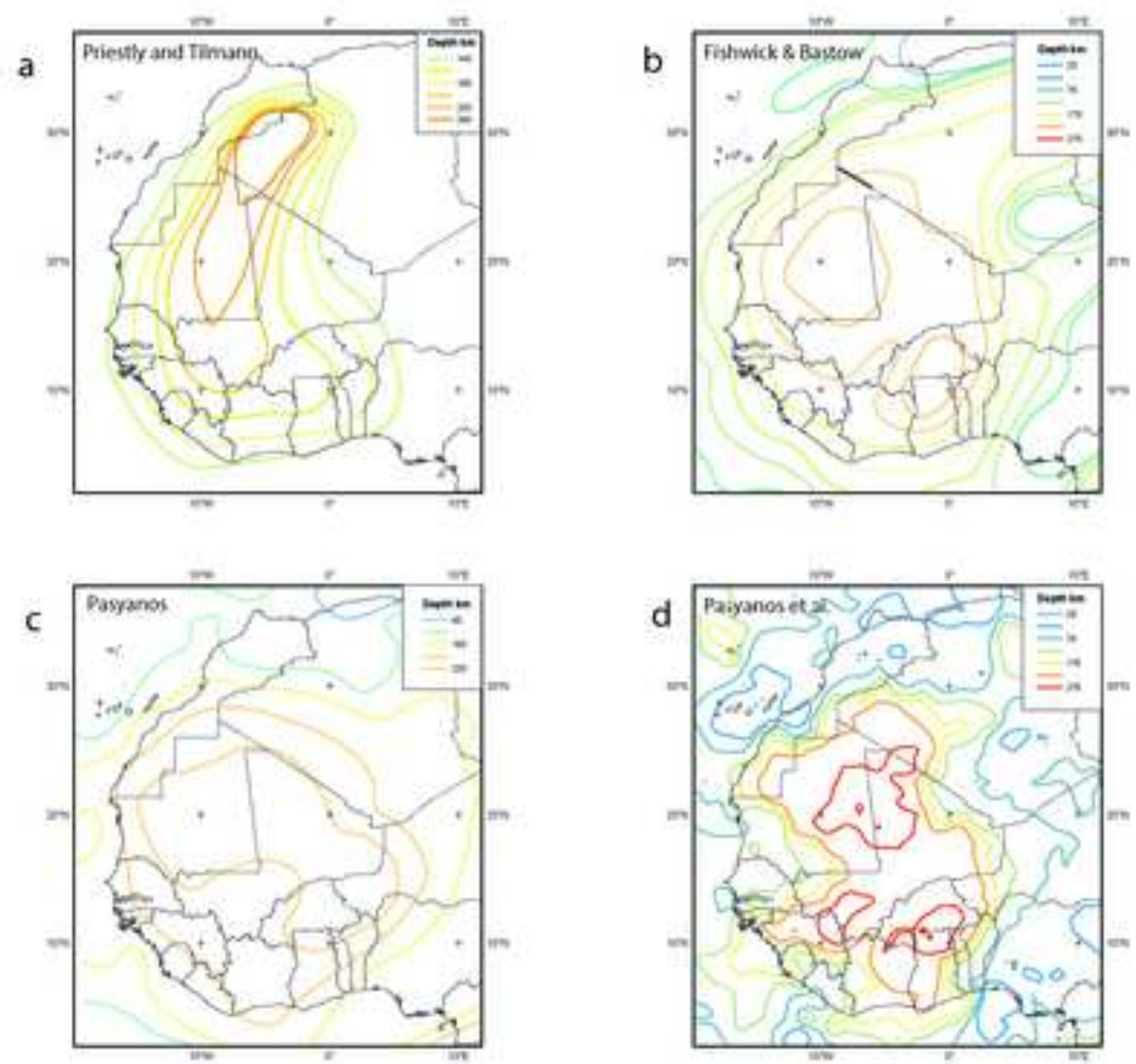


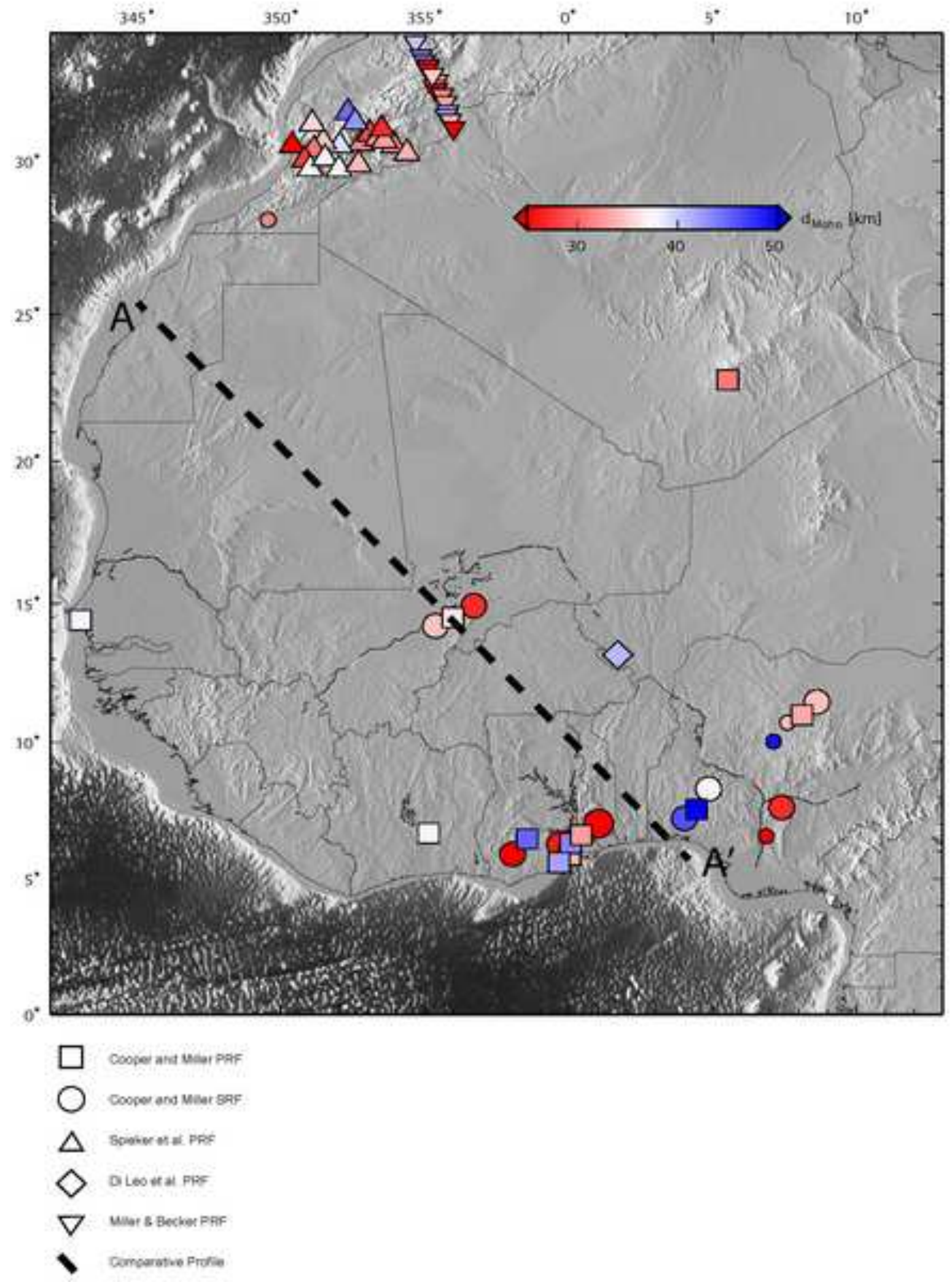

Fig 5 a 


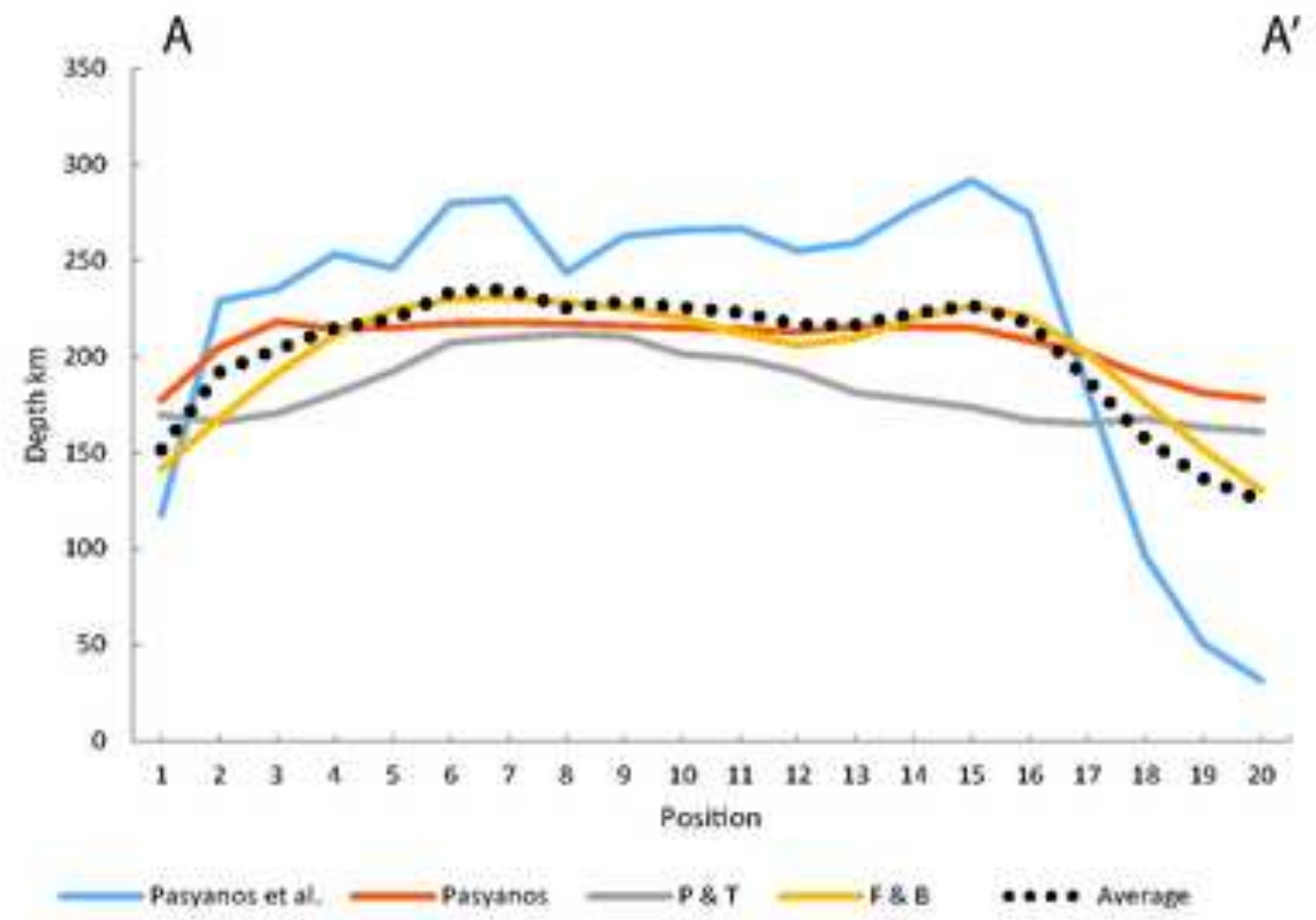

Figure $5 b$

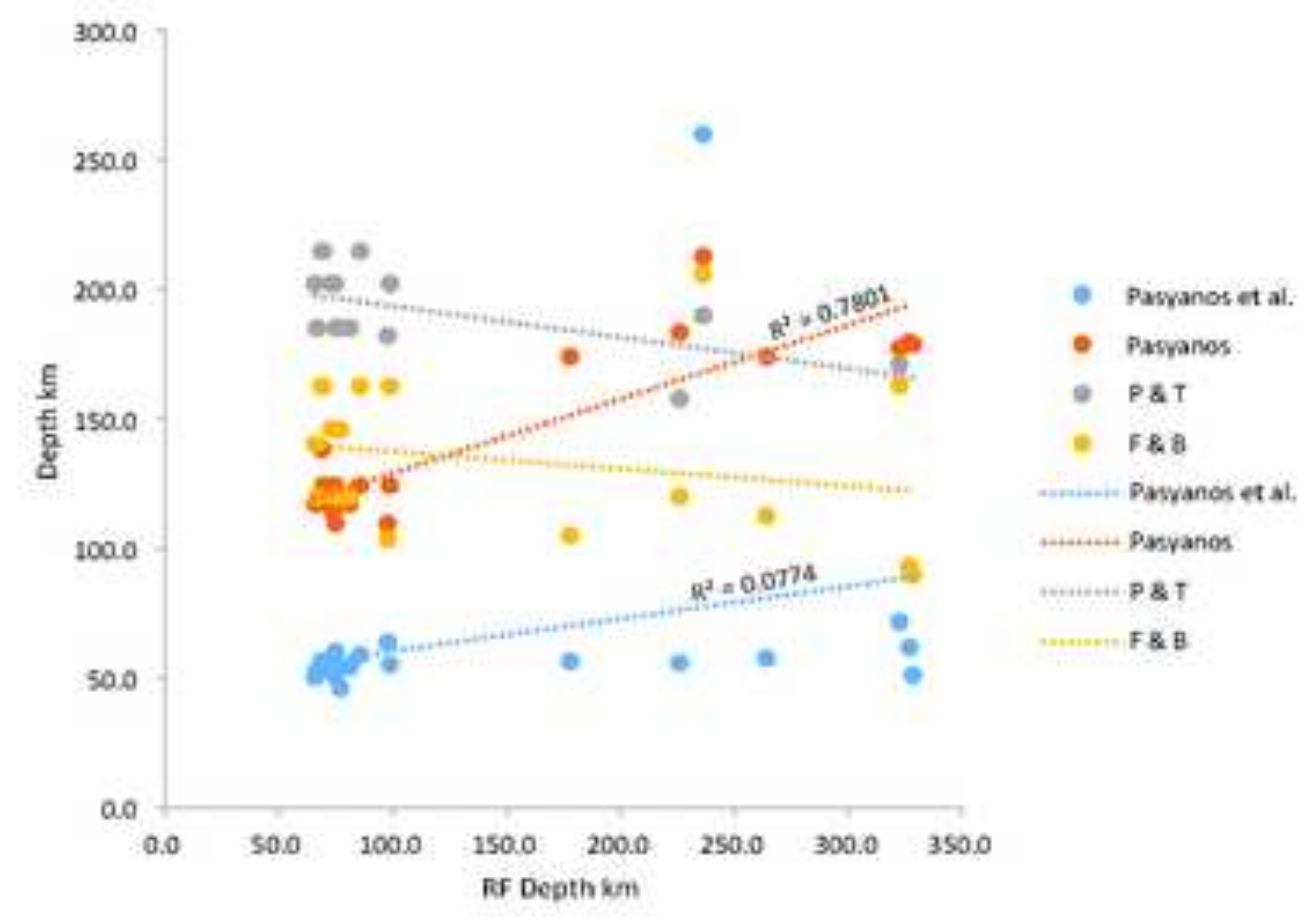

Figure $5 c$

Figure $5 b c$ 


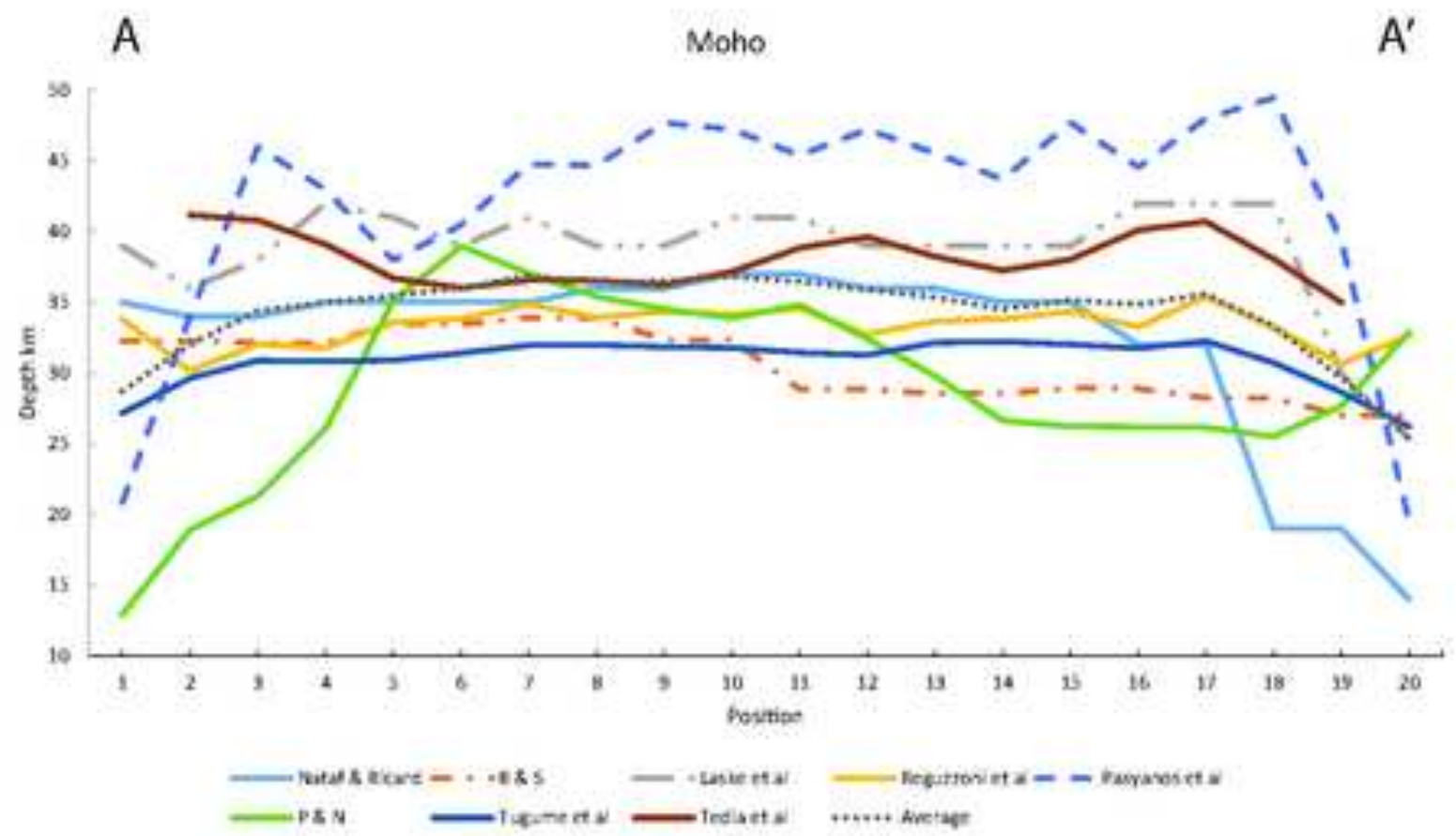

Figure 5d

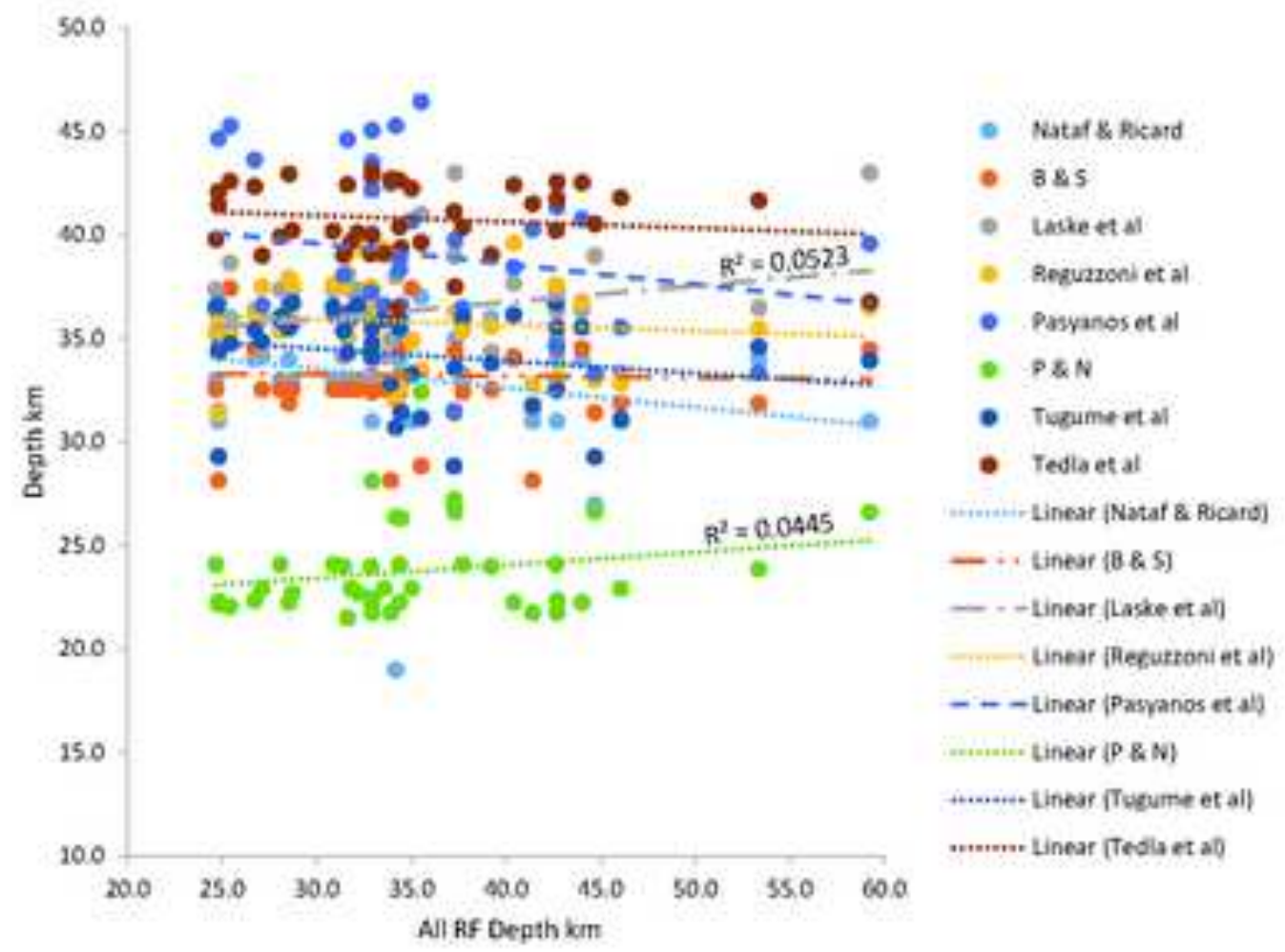

Figure 5 e 


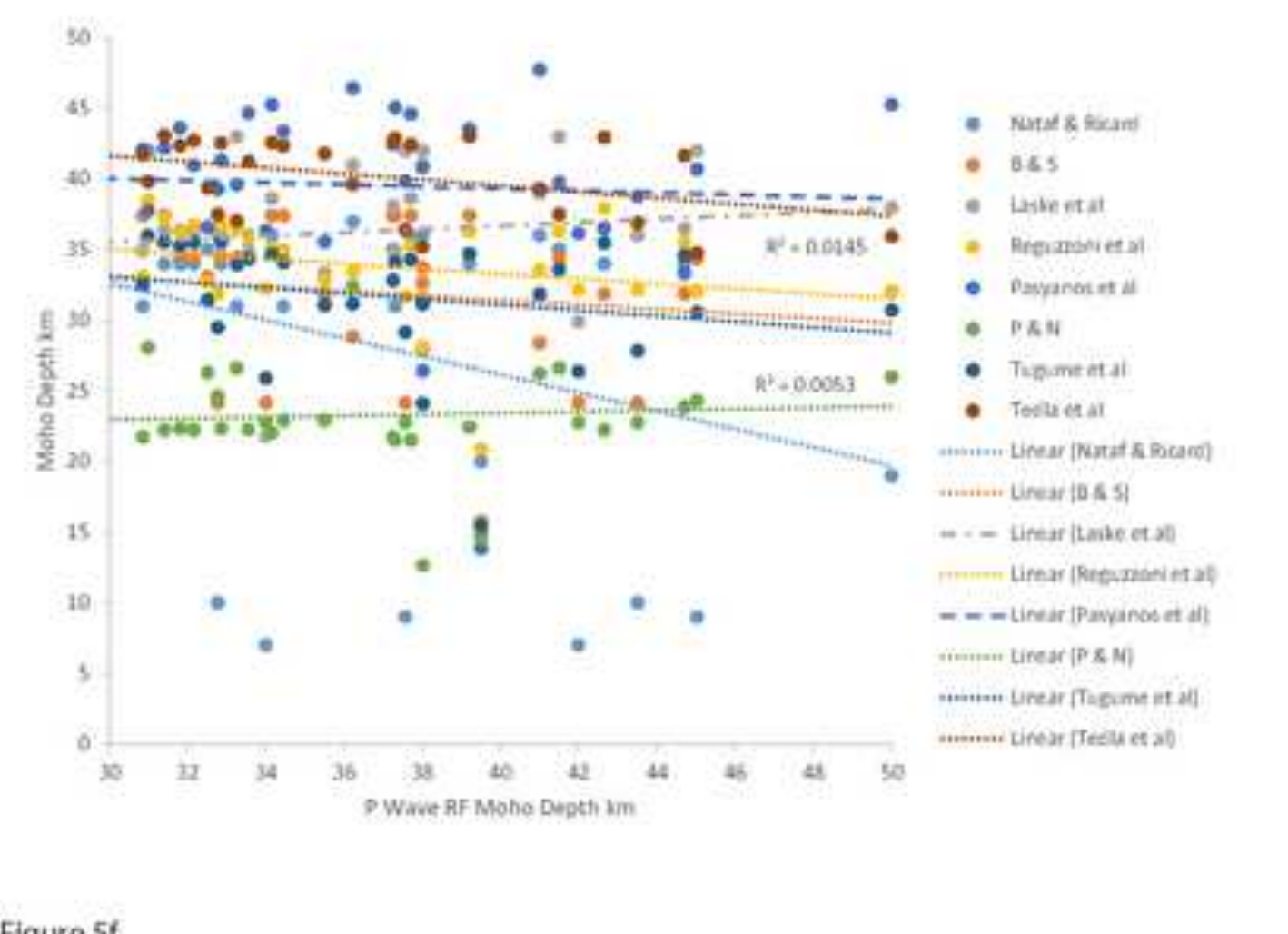

Figure $5 f$

Figure $5 f$

\section{f}

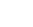

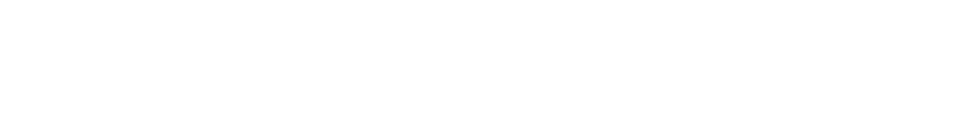

(1)

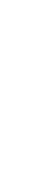

\section{.}

(1)

the

(1)

(1)

(n)

(

(1)

ta

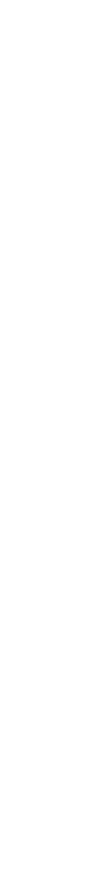

(n)

\section{(a)}


a

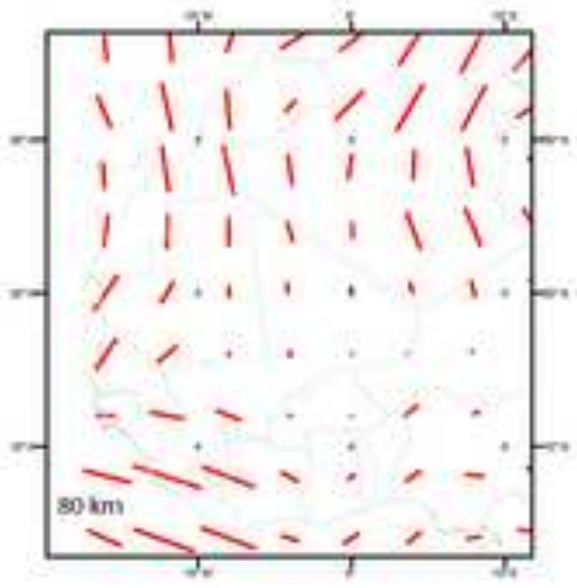

b

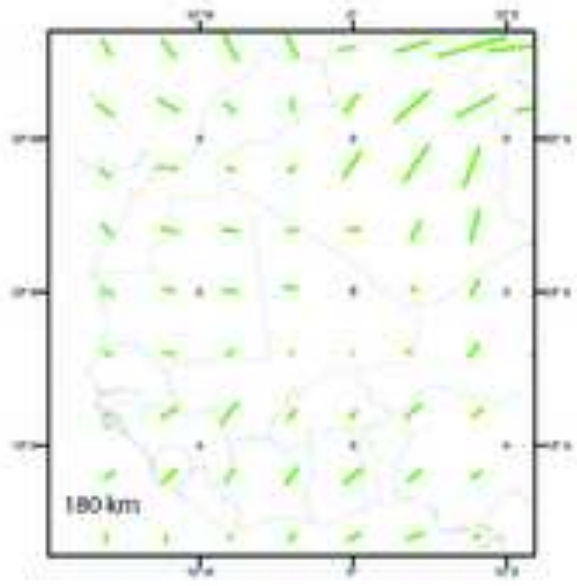

c

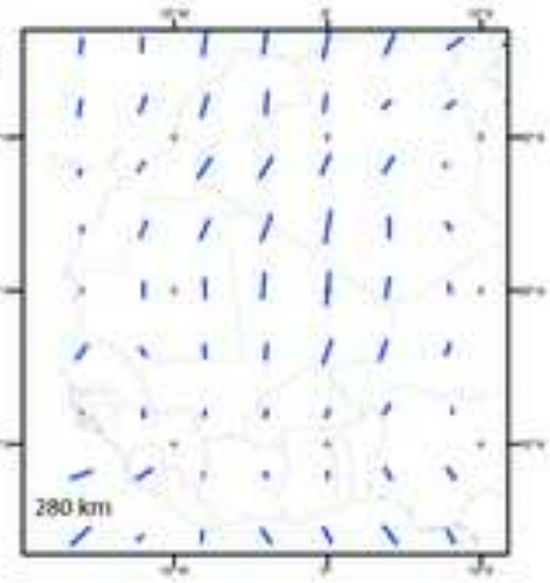

$500 \quad 1000$ 

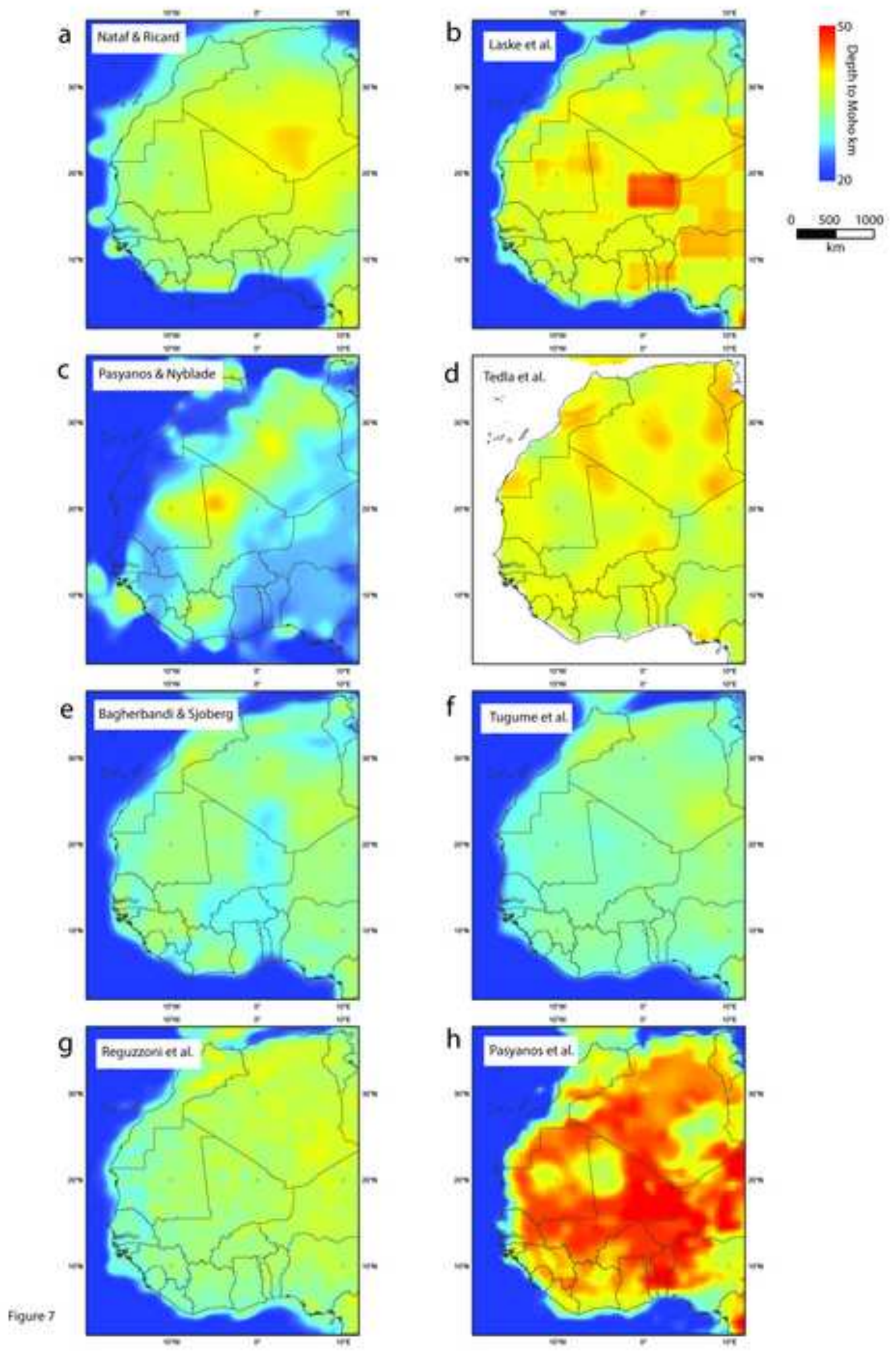

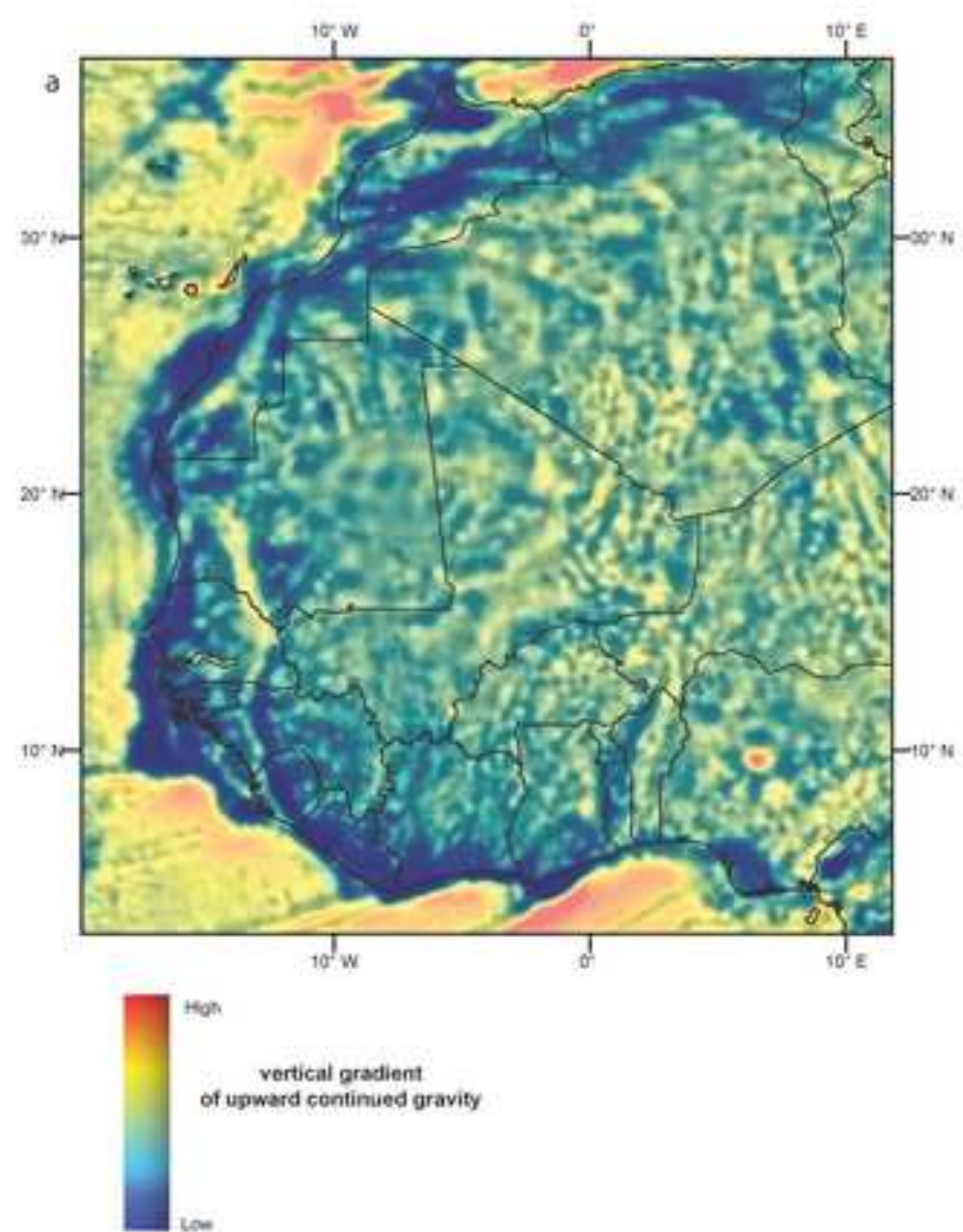
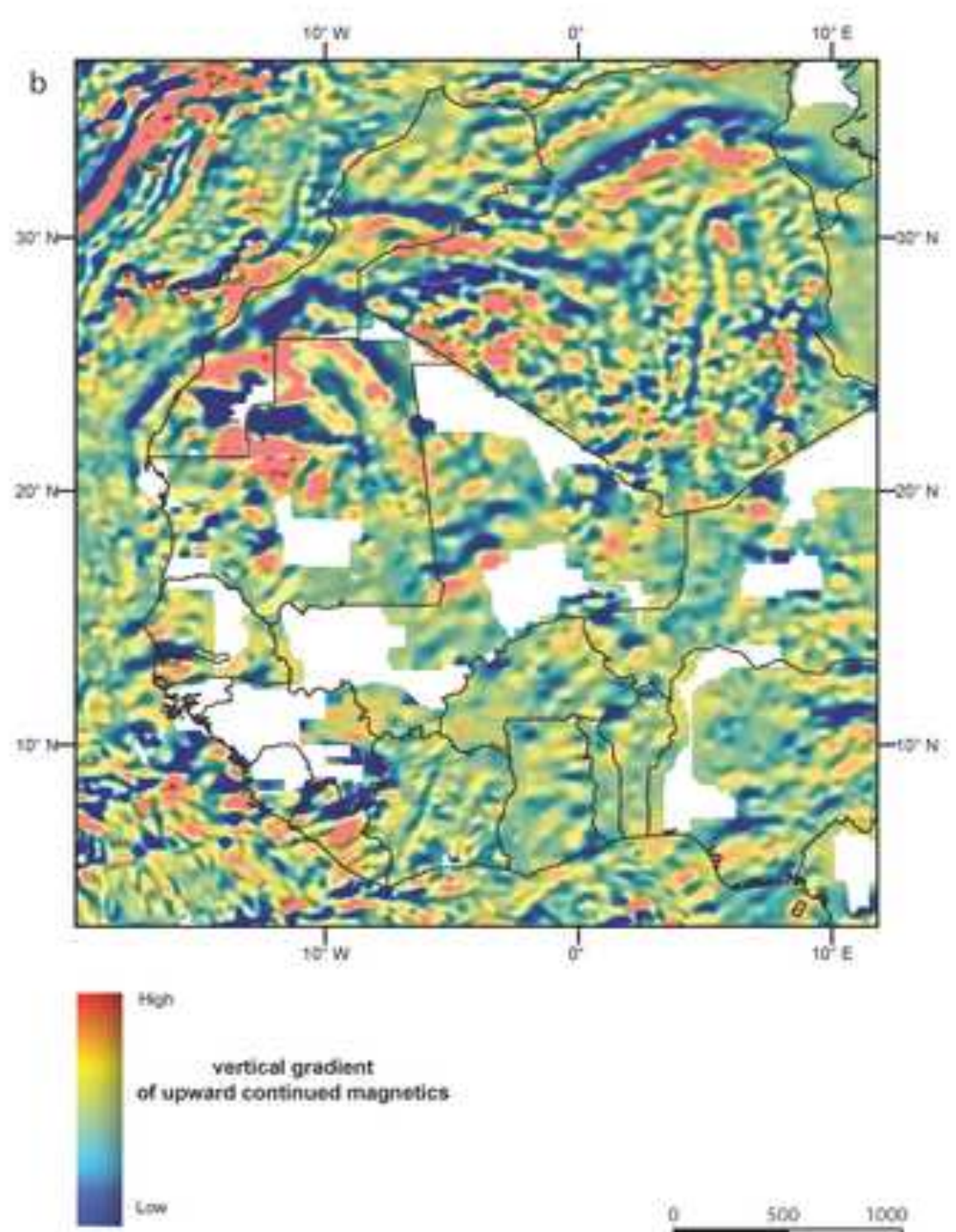

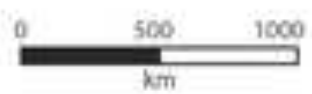



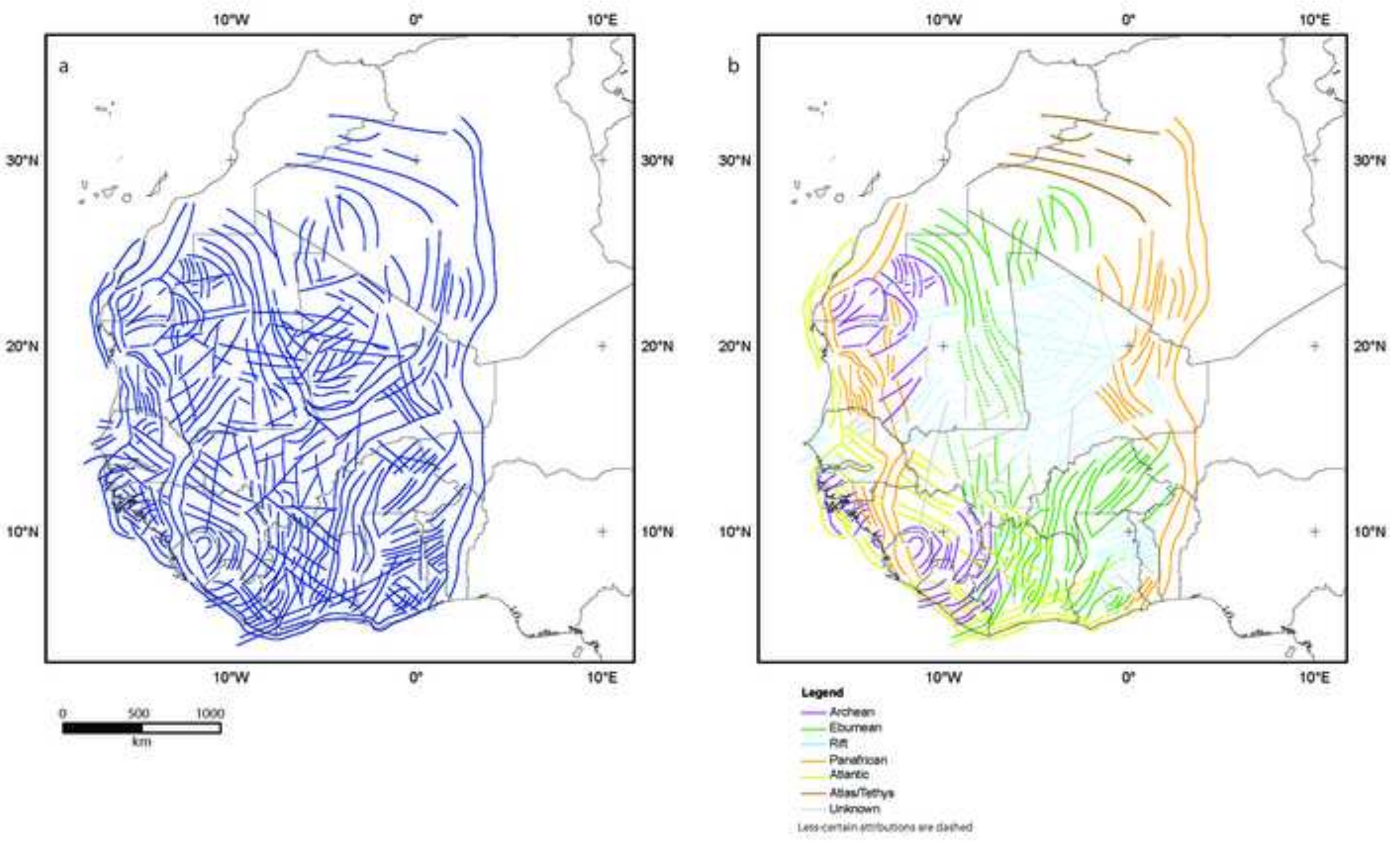

Figure? 

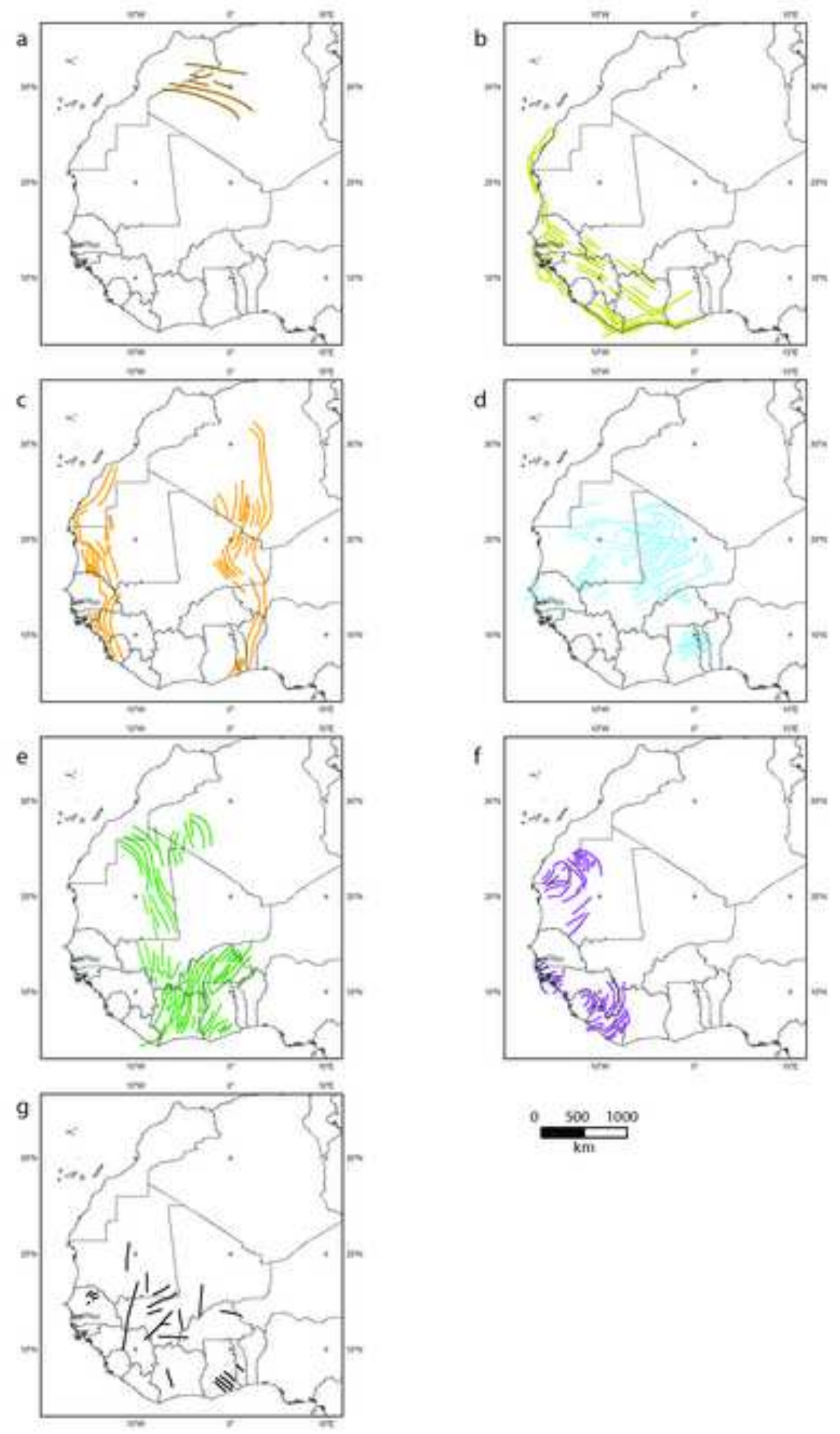

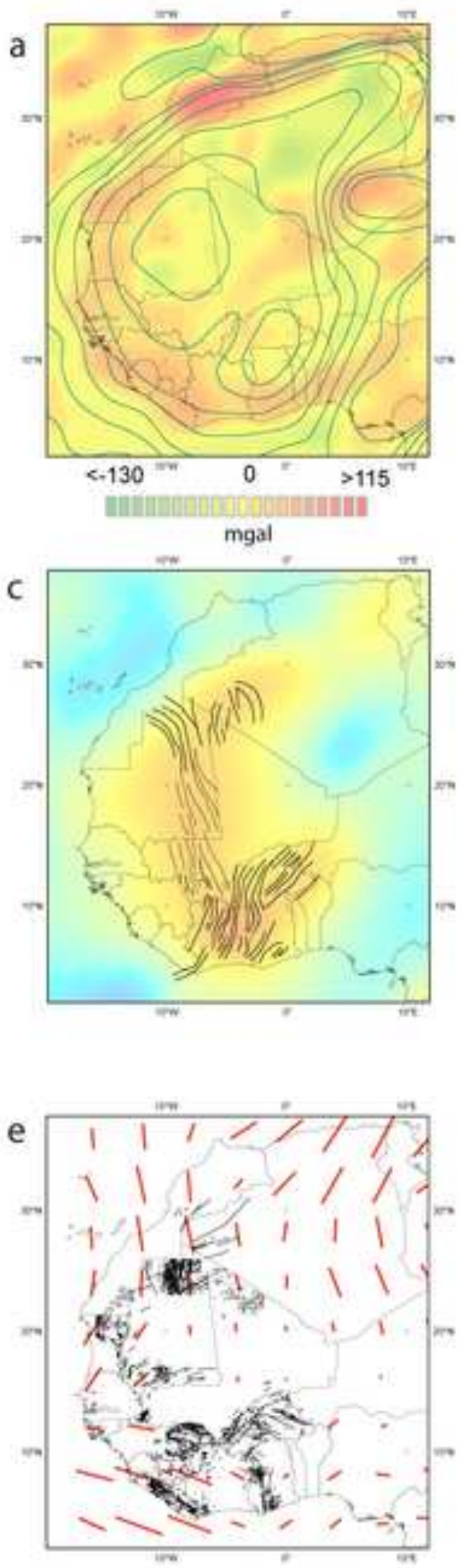

-Mafic dykes (Jessell et al., 2015)

-Vs Anisotropy $80 \mathrm{~km}$ (Sebai et al,, 2006)
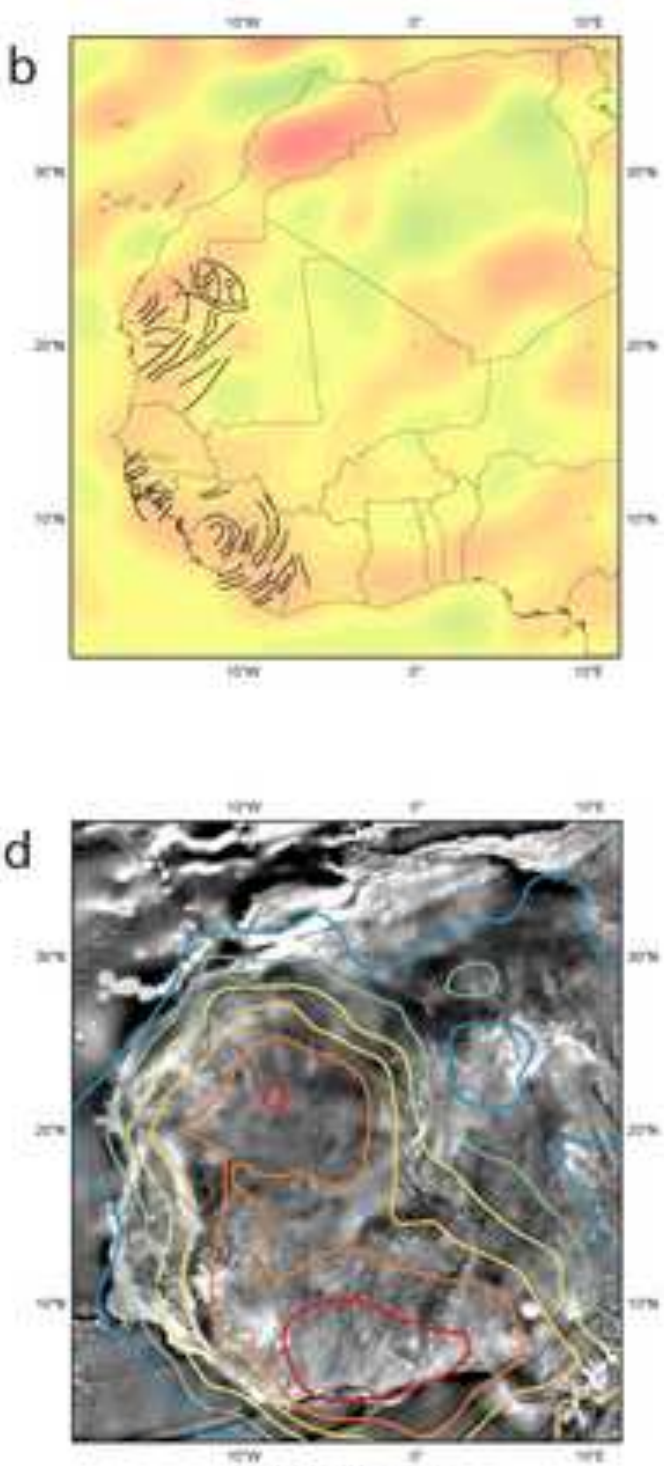

Free Air Gravity

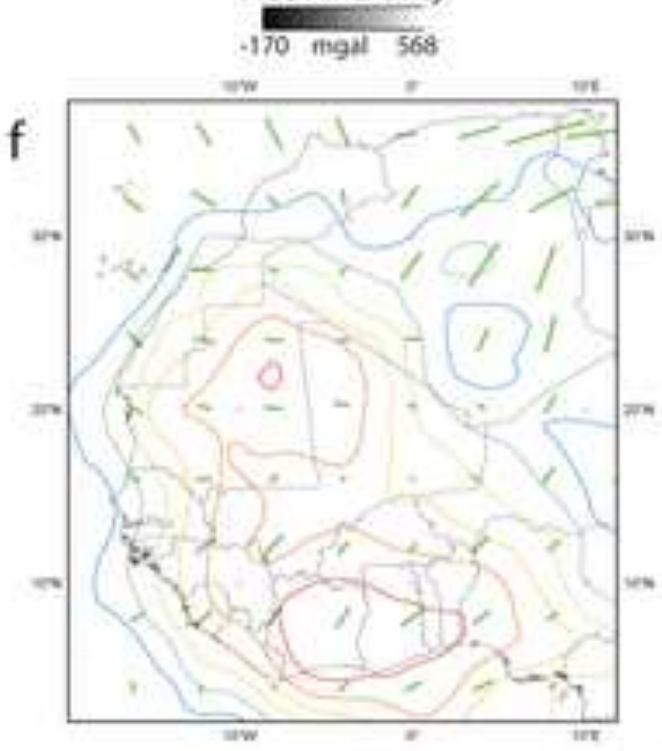

-Vs Anisotropy $180 \mathrm{~km}$ (Sebai et al., 2006) 


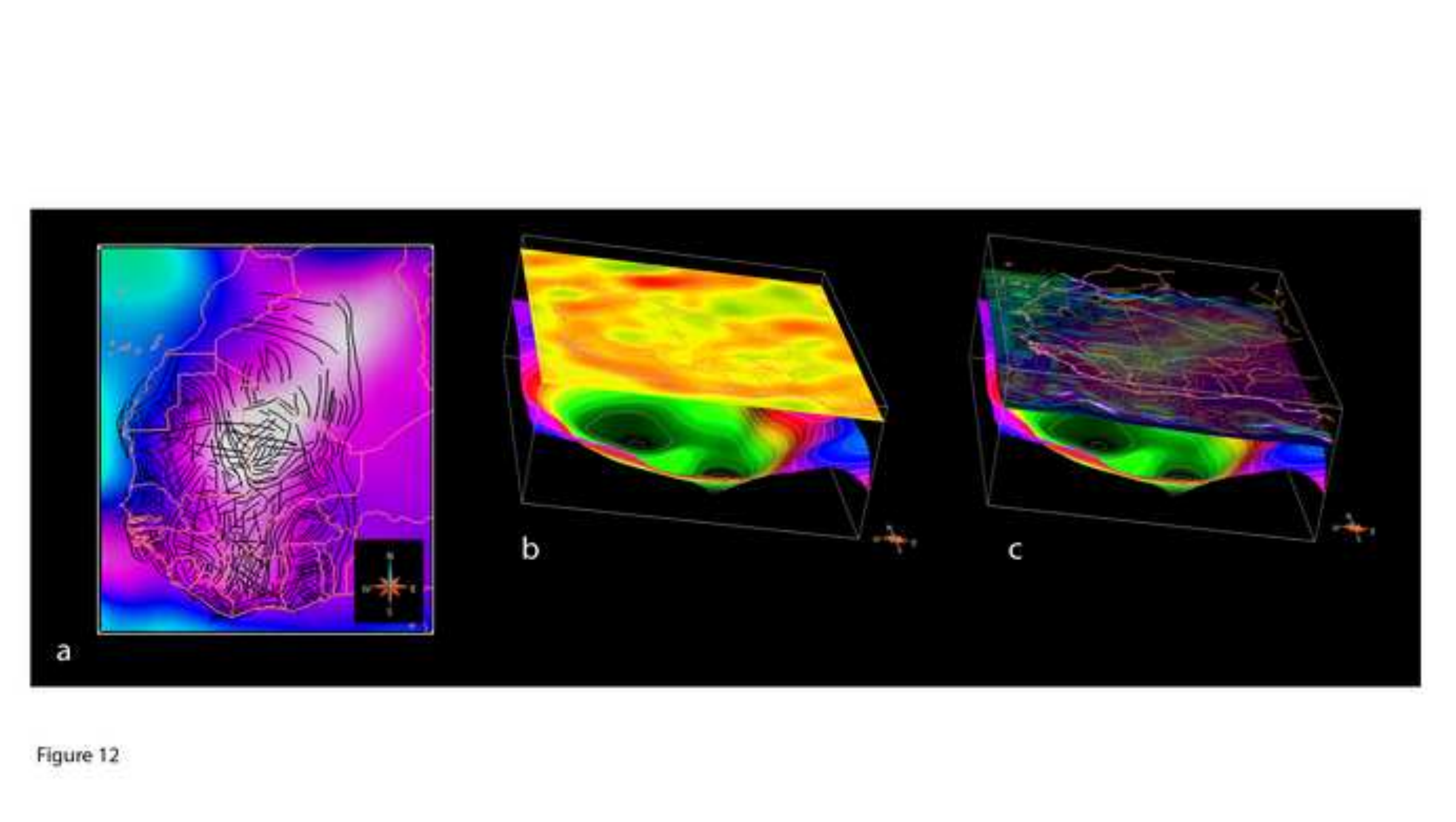

Figure 12

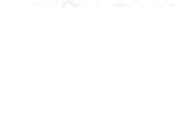

2
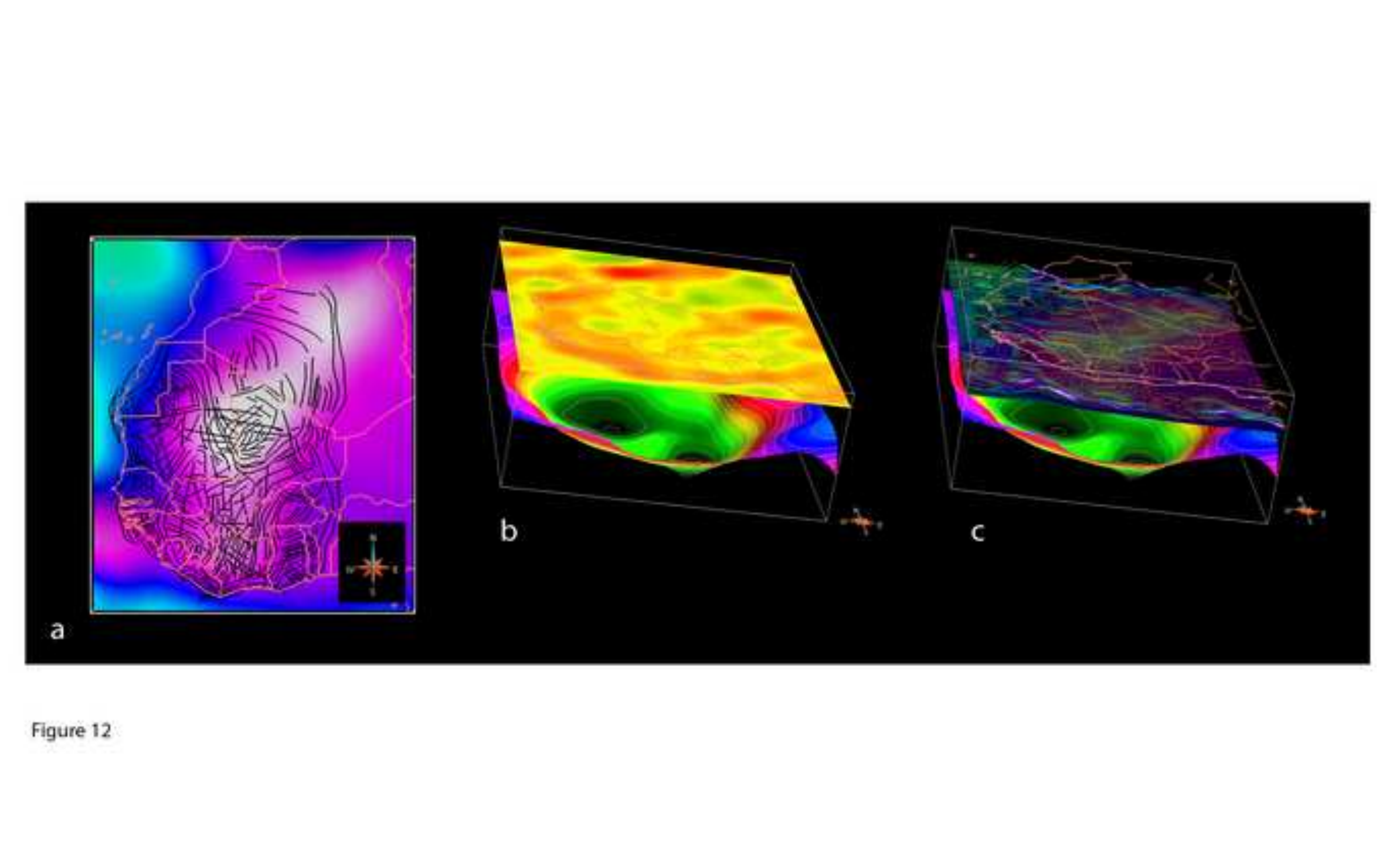

\section{Figure 1}

.

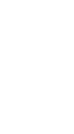

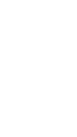

